\title{
What determines technological hits? Geography vs. firm competencies
}

Citation for published version (APA):

Myriam, M. (2004). What determines technological hits? Geography vs. firm competencies. MERIT, Maastricht Economic Research Institute on Innovation and Technology. MERIT-Infonomics Research Memorandum Series No. 004 https://doi.org/10.26481/umamer.2004004

Document status and date:

Published: 01/01/2004

DOI:

10.26481/umamer.2004004

Document Version:

Publisher's PDF, also known as Version of record

\section{Please check the document version of this publication:}

- A submitted manuscript is the version of the article upon submission and before peer-review. There can be important differences between the submitted version and the official published version of record.

People interested in the research are advised to contact the author for the final version of the publication, or visit the DOI to the publisher's website.

- The final author version and the galley proof are versions of the publication after peer review.

- The final published version features the final layout of the paper including the volume, issue and page numbers.

Link to publication

\footnotetext{
General rights rights.

- You may freely distribute the URL identifying the publication in the public portal. please follow below link for the End User Agreement:

www.umlib.nl/taverne-license

Take down policy

If you believe that this document breaches copyright please contact us at:

repository@maastrichtuniversity.nl

providing details and we will investigate your claim.
}

Copyright and moral rights for the publications made accessible in the public portal are retained by the authors and/or other copyright owners and it is a condition of accessing publications that users recognise and abide by the legal requirements associated with these

- Users may download and print one copy of any publication from the public portal for the purpose of private study or research.

- You may not further distribute the material or use it for any profit-making activity or commercial gain

If the publication is distributed under the terms of Article $25 \mathrm{fa}$ of the Dutch Copyright Act, indicated by the "Taverne" license above, 


\section{MERIT-Infonomics Research Memorandum series}

What determines technological hits?

Geography vs. firm competencies.

\section{Myriam Mariani}

2004-004

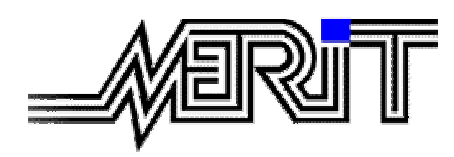

MERIT - Maastricht Economic Research Institute on Innovation and Technology

PO Box 616

6200 MD Maastricht

The Netherlands

$\mathrm{T}:+31433883875$

F: +31433884905

http://www.merit.unimaas.nl

e-mail:secr-merit@merit.unimaas.nl

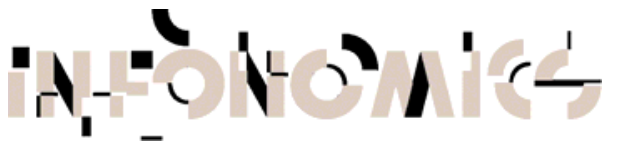

International Institute of Infonomics

c/o Maastricht University

PO Box 616

6200 MD Maastricht

The Netherlands

T: +31433883875

F: +31 453884905

http://www.infonomics.nl e-mail: secr@infonomics.nl 


\title{
What determines technological hits? \\ Geography vs. firm competencies
}

\author{
Myriam Mariani \\ MERIT, University of Maastricht, Maastricht, the Netherlands and \\ University of Camerino, Camerino, Italy \\ m.mariani@merit.unimaas.nl
}

\begin{abstract}
This paper uses a novel database composed of 4,262 European chemical patents applied for by 693 firms during 1987-1996 to compare the relative effect of firm and regional characteristics on the production of technological hits (highly cited patents). By using an extensive set of controls, the main finding of the paper is that in the "traditional" chemical sectors technological hits are explained only by firm-level economies of scale and scope in R\&D. Firm competencies - i.e. technological specialisation - are still important in biotechnology. However, what really distinguishes the biotech model is that localised knowledge spillovers also matter. I argue that the centrality of firms vis-à-vis regions underlines a more general contrast between two different models of producing innovations.
\end{abstract}

Keywords: firm competences, geographical spillovers, patents, patent citations

JEL classifications: O30, O18, O31 


\section{Introduction}

There is consensus in the literature on the importance of firm competencies in the production of innovations. (See for example Nelson and Winter, 1982; Dosi et al. 1988; Klepper, 2001). The affiliation to a certain organisation with its unique competencies, its internal communication systems, and the routines that it develops over time is a mechanism through which knowledge is produced and transmitted among different individuals and parts of the firm.

Another stream of the literature highlights an alternative model for organising innovative activities: the geographical cluster that helps knowledge to be efficiently transferred among agents and translated into innovations. By arguing that outside sources of knowledge are critical to the innovation process, and that knowledge spillovers are more pronounced when the relevant agents are geographically close, this literature explains the tendency of innovative activities to cluster. (See, for example, Jaffe, 1986; Jaffe et al., 1993; Audrestch and Feldman, 1996; Caniels, 1999; Swann et al. 1998).

To my knowledge, however, little work has been done in the literature to compare the relative importance of these two models in explaining the value of innovations. This is the goal of the present paper. It explores empirically how much of the value of an innovation is affected by the affiliation of the inventors to the same organisation as opposed to spillovers that arise when the inventors are geographically close to each other and to external sources of knowledge. The answer to this question will shed some light on the mechanisms through which knowledge is generated, and on the performance of

I thank Ashish Arora, Alfonso Gambardella, Marco Giarratana, John Hagedoorn, Bronwyn Hall, Dietmar Harhoff, Steven Klepper, Pierre Mohnen and Pierre Regibeau for helpful comments. I also thank Bart Verspagen for providing me with patent citations, and Rossana Pammolli for developing a correspondence table between the IPC classes and the 5 chemical sectors used in this paper. Useful comments were made by the participants to the EPIP conference (European Policy for Intellectual Property, Munich 2003) and to the Innogen workshop (Innovation, Growth and Market Structure, London 2003). Support from the European Commission TMR “Marie Curie Fellowship” (Grant \# HPMF-CT-2000-00694) and from the European Commission Key Action "Improving the Socio-Economic Knowledge Base" (Contract \# HPSE-CT-2002-00146) is acknowledged. The usual disclaimers apply. 
different coordination mechanisms in industries characterised by different technological regimes - biotechnology vs. traditional chemicals.

The empirical investigation uses a novel and detailed dataset constructed specifically for the purpose of analysing this issue, and composed of a randomly selected sample of 4,262 chemical EPO patents applied for by 693 firms and invented in 208 European regions during 1987-1996. To test the effect of firm and regional characteristics over the probability of producing technological hits, the paper performs a Negative Binomial regression. The number of citations received by the patents after the application date is used as a proxy for the value of the innovations. This is regressed on firm characteristics (sales, R\&D expenditures, past patents as a proxy for technological competencies), characteristics of the innovation project (e.g. number of inventors in the patents), scientific and technological characteristics of the regions in which the patents are invented, and a set of controls.

The main finding of the paper is that valuable innovations in biotech and in the traditional branches of the chemical industry are the outcome of different models. Firm competencies, and specifically R\&D economies of scale (large research projects) and scope (R\&D intensity at the firm level) explain a good deal of the probability of developing valuable innovations in the traditional chemical sectors. In these sectors knowledge spillovers external to the firm do not add much to the probability of producing technological hits. Firm competencies - and specifically firm technological specialisation - are still key factors in biotechnology. Differently, however, biotech innovations benefit from the geographical proximity of the inventors to external sources of knowledge. These results are consistent with other work in the literature. For example, after controlling for the spatial distribution of production activities, Audretsch and Feldman (1996) show that innovative activities cluster more in skilled and R\&D intensive industries. Klepper (1996) demonstrates that the stage of the industry life cycle influences the geographical agglomeration of innovative activity. More precisely, innovative activity in the early stages of an industry life cycle benefits the most from locally bounded knowledge spillovers as compared to the mature or declining stages. Finally, Zucker, Darby and Armstrong (1998) show that geographical proximity to university research - which 
materialises in working relationships between the firm and the top scientists in the academia - positively affects firm R\&D productivity in biotechnology.

After a review of previous studies on firm competencies, geographical spillovers and the use of patent citations (Section 2), Section 3 describes the dataset and presents some insights from the data. Section 4 formulates an empirical model that explains the probability of inventing valuable innovations in biotechnology and in traditional chemicals as a function of firm and regional characteristics. Section 5 adds empirical evidence to the econometric estimates, and Section 6 concludes the paper.

\section{Firm, geography and the value of innovations}

\subsection{Firm competencies and geographically localised spillovers}

While the motives and the benefits that arise when scientists collaborate are well understood (see, among others, de Solla Price and Beaver, 1966; Merton 1973; Narin and Withlow, 1990), the mechanisms that give rise to research collaborations and the means through which knowledge is efficiently transferred among individuals remain relatively unknown. When these issues are explored, the firm is described as the natural mechanism to foster and coordinate research activities (Nelson and Winter, 1982; Dosi et al. 1988; Patel and Pavitt, 1997). This is because the firm develops specific competencies, learning processes, communication systems and routines that help reduce the cost of coordination of different parts of the organisation, different projects and individuals. These firm specific mechanisms help explain the persistent different performance of firms in terms of innovativeness, competitiveness and growth (Nelson, 1995).

Klepper and Sleeper (2002) describe the parental origins of firms' distinctive capabilities for spinoff companies, and argue that these capabilities are difficult to reproduce without transferring the human capital employed by the companies. On the same line, Teece et al. (1997) point out that firm specific capabilities to coordinate and integrate internal activities, the effectiveness of the internal learning processes, and the ability to modify strategies and competencies when the outside conditions change are important factors in 
explaining firms’ competitive advantage. (See also Levinthal and March, 1993; and Christensen, 1997).

A growing body of literature has emphasised another means, possibly alternative to the firm, to coordinate individuals, production and research activities: the geographical cluster. The literature on clustering shows that there are different motives for the geographical concentration of innovative activity. First, innovation processes are complex and uncertain. Since complexity and uncertainty can be reduced by accessing information, by monitoring other people behaviour, and by fostering communication among individuals, and since communication is, in turn, negatively influenced by distance, people tend to locate close to each other. Second, innovative activities cluster geographically because they benefit from localised technological spillovers that foster knowledge exchange and increase the returns from the investment in R\&D. (See, for example, Jaffe, 1986; Jaffe et al., 1993). This is particularly so when knowledge especially "new knowledge which tends to be informal and uncodified” (Pavitt, 1987) is involved in the production of other knowledge or information, and when it relies on practice and learning-by-doing. Finally, knowledge is cumulative also at the geographical level. Therefore, scientific and technological progress is faster in regions that have accumulated high levels of innovative activities over time.

The empirical evidence supports the idea that the cost of transmitting knowledge rises with geographical distance, and confirms that innovative activities concentrate geographically. Some contributions measure the geographical extent of knowledge spillovers (Swann et al., 1998; Verspagen, 1997), while others study the effect of spillovers on regional economic growth (Caniels, 1999). Others, still, emphasise that there are sectoral differences in spatial clustering with some industries that benefit more from being co-localised. Particularly, in new and knowledge driven industries, where technologies develop rapidly and where research brings about big technological discontinuities and relies on a wide range of competencies, firms tend to establish formal and informal relationships with other organisations for the exchange knowledge. Audretsch and Feldman (1996) show that innovative activities cluster more in skilled and R\&D intensive sectors, with industries like computer and pharmaceuticals displaying a 
higher degree of concentration compared to all manufacturing. Breschi (1999) derived similar conclusions by examining patent data from the European Patent Office. Klepper (1996) demonstrates that the stage of the industry life cycle influences the geographical agglomeration of innovative activity: innovative activity in the early stages of an industry life cycle benefits the most from locally bounded knowledge spillovers as compared to the mature or declining stages.

This is so, for instance, in biotechnology, a relatively new and knowledge-based industry composed of a large number of small firms. (See Orsenigo, 1989). Powell et al. (1996) show that in the biotechnology industry, the locus of innovation is in the network of different organisations, rather then in individual firms. By using data on the formal agreements set up by 225 biotechnology firms they map the network structure of the industry, and argue that firms collaborate to expand their competences. To highlight this point they describe two important biotech discoveries in the mid ' 90 s that are coauthored by more than 30 researchers located in a wide range of different organisations. On the same line, Zucker, Darby and Brewer (1998) show that in the case of the US biotech industry, the growth and location of intellectual human capital - i.e. basic scientific research - was the main determinant of the growth and location of the industry. Zucker, Darby and Armstrong (1998) demonstrate that geographical proximity to university research - which materialises in working relationships between the firm and the top scientists in the academia - positively affects firm R\&D productivity in biotechnology, and argue that such spillovers do not occur unintentionally, but rather depend on specific complementary actions of the economic agents. (See also Arora et al., 2001). Based on these contributions, my expectation is that firm competencies are a crucial asset for developing valuable innovations both in the science-driven biotech sector and in the more mature and scale-intensive chemical industry. However, I expect that the biotech model of innovation relies on nearby scientific and technological sources more than the traditional chemical model of innovation where spillovers are at work within the same large firm.

\subsection{The value of innovations and patent citations}


My empirical investigation uses a sample of 4,262 patents applied at the EPO in the period 1987-1996, and exploits a number of information contained in the patent document, like the name of the applicants, the name of the inventors, the country and address in which both the applicants and the inventors are located, the IPC technological class, the year of the application, and the number of citations to previous patents. In particular, this paper uses the number of citations received by the patent in the five years after the application date as a proxy for the value - or at least the importance - of the innovations.

The use of patent citations is now fairly standard in the literature (for a survey see Hall et al., 2001). Citations made to previous patents are used as indicators of knowledge spillovers from the cited to the citing patent (see, for example, Jaffe et al. (1993) for the use of patent citations as indicators of spillovers over geographical distance), while citations received by a patent after the publication date are good proxies for the importance of the patent. Several contributions demonstrate that there is a positive relationship between patent indicators that appear after the innovation has been discovered and the ex-post value of the innovation as given by traditional accounting evaluation (See, for example, Hall et al., 2000).

A classical contribution is Trajtenberg (1990), who shows that there is a non-linear and close association between patent counts weighted by forward citations and the social value of innovations in the Computer Tomography Scanner industry. Harhoff et al. (1999) demonstrate that the number of backward citations either to other patents or to non-patent literature, as well as the number of citations received by the patent after its publication is positively correlated with the value of the innovations. This also applies to patents that incur in opposition and annulment procedures, and to patents that are applied for in many countries. Griliches et al. (1987) use data on patent renewal rates and fees to estimate the private value of patent rights. Lanjouw and Schankerman (2004) use multiple indicators - number of claims, forward citations, backward citations and patent family size - to construct a composite measure of the quality of patents. They also show that forward citations, together with the number of claims, are the least noisy indicators of the value of innovations. 
Unfortunately, if patent indicators and patent citations in particular are an immense source of information for scholars in the economics of innovation and technical change, they have a number of limitations as well (Griliches, 1990). For example citations cannot be made to or by innovations that are not patented, thus underestimating the actual importance of some of them. Second, there is the so called "truncation" problem: as the time series move closer to the latest date in the data set, patent citations increasingly suffers from missing observations. Third, not only is the number of citations received by any patent truncated in time, but patents applied in different years and technological classes might differ in their propensity to be cited. Hall et al. (2001) show that the number of USPO citations made per patent has increased over time due to the higher propensity to cite in recent years and to the steep raise in the number of patents issued. All this suggests that changes in the number of citations per patent might stem from factors other than the actual changes in the technological impact of the innovations. Hall et al. (2001) describe two possible remedies for these problems. One of them is to scale citation counts by the average number of citations of a group of patents to which the patent of interest belongs. The econometric investigation in this paper does not ignore these problems, and uses the idea suggested by Hall et al. (2001) to solve some of them.

\section{Sample and methodology}

\subsection{Data}

The main source of data for the empirical investigation is the European Patent Office (1998). This paper exploits the wealth of patent information by linking them to other sources of data concerning the characteristics of the firms and the locations in which the innovations are developed.

I started by selecting a random sample of 10,000 EPO patents from a database of 201,531 chemical patents applied for between 1987-1996 (European Patent Office, 1998). Since I have complementary data only for the European regions, I dropped from this sample the patents for which none of the inventors had a European address. This produced a sample of 4,649 patents for which at least one inventor is located in Europe. I checked the 
features of this sample, and they are fairly representative of the whole population. Also the choice of the chemical industry is not accidental. First of all, since the propensity to patent chemical innovations is higher than in other sectors, chemical patents are a good source of information on the innovation process and its outcomes. Second, the chemical industry is heterogeneous, ranging from bulk chemicals to specialty chemicals, pharmaceuticals and biotechnology, and therefore it offers an interesting basis for exploring in detail the presence of different R\&D strategies and innovation models in sectors with different characteristics.

I asked an expert pharmacologyst to read the abstracts of the patents and the description of the 3-digit IPC codes (International Patent Classification) of the main/obligatory technological class of the patents. This information was used to assign the 4,649 patents to 5 technological classes: biotechnology, materials, organic chemistry, pharmaceuticals and polymers. From the patent document I collected other information on the innovation: the name of the applicants, the name of the inventors, the country and addresses in which the applicants and the inventors are located, the number of countries in which the patent was applied for, the year of the application, and the number of citations to previous patents in each year after the patent application up to 2000 .

By using the zip code contained in the address of the inventors each patent was assigned to the specific NUTS region in which it was invented at the most disaggregated NUTS3 and NUTS2 level (see Appendix 1 for the list of NUTS3 and NUTS2 regions used in this paper). ${ }^{1}$ For patents invented by multiple inventors located in different regions (33.5\% of the total sample), I assigned the patent to the region in which the largest share of inventors was located. When the share was $50 \%$ of the inventors in one region, and the other $50 \%$ in another one, I assigned the patent to the first inventor of the list. Even if there is clearly some degree of arbitrariness in assigning patents to locations when the

\footnotetext{
${ }^{1}$ The Nomenclature des Unités Territoriales Statistiques is a Eurostat classification that subdivides the European Union in groups of regions (NUTS1), regions (NUTS2) and provinces (NUTS3). In order to have a certain degree of homogeneity in the size of the regions I used the most disaggregated NUTS3 regions for Austria, Denmark, Spain, Finland, France, Italy and Sweden, and the NUTS2 classification for Belgium, Germany, Greece, the Netherlands, and the UK. Luxemburg, Ireland and Switzerland were considered as a whole.
} 
inventors are located in different regions, the problem is confined to $24 \%$ of the patents for which the assignment was based on the region with the highest share of inventors, and $9.5 \%$ of the patents for which the assignment was based on the 50-50 rule. At any rate, I also control for these patents in my regressions by including a dummy for whether the inventors are all located in the same region (co-localised inventors) as opposed to having at least one inventor in a different region. ${ }^{2}$

Data about the characteristics of the regions such as the GDP, the population, the size, the total number of patents invented in the area in the period 1987-1996 are drawn from the EUROSTAT REGIO database (1999). I also employed the European R\&D database (Reed Elsevier Publisher, 1996) that collects the number and type of R\&D laboratories in Europe to download a stock of about 20,000 laboratories located in Europe (as for December 1995). They are classified as private laboratories if they are owned by private companies, higher education laboratories if they are university research centres, government laboratories if they are hospitals or government laboratories, and chemical laboratories if they focus on chemical research. Each laboratory was also assigned to its NUTS region.

The names of the applicants of the patents were used to collect information on the organisations to which the inventors are affiliated. Their composition is as follows: 166 patents are applied for by public institutions, excluding universities; 45 are done by universities; 134 are individual inventors (i.e. applicants who do not belong to any firm); the remaining 4,262 patents are applied for by 693 firms. I decided to confine the analysis to the patents applied for by the private companies. The names of the applicants of these 4,262 patents were standardised in order to merge parent and affiliate firms under the same name. The Who Owns Whom database (1995) was used to investigate these parental relations.

\footnotetext{
${ }^{2}$ I also checked the address of the inventors on the map by using Autoroute 2000. In a few cases in which the inventors were located on the border between different regions I treated them as if they were located in only one region, and followed the rule described above to classify them.
} 
To collect company data, I used different sources. ${ }^{3}$ First, Aftalion (1991) lists the top 250 chemical companies worldwide in 1988, and provides firm-level information on R\&D spending, total turnover and chemical turnover. This ensured that I covered the most important chemical firms in my sample. I complemented the Aftalion data with sales and R\&D information from Compustat (1999). Finally, I searched in the Internet for information on some smaller concerns. In the end I was unable to find information on a tail of applicants covering 852 patents in the sample. These are fairly unknown firms with 1 or 2 patents in my sample, and their distribution across regions and technological classes is not biased in any particular direction. Nevertheless, as we shall see in the econometric section, I used the observations for these patents by including a dummy for the missing sales and R\&D values. ${ }^{4}$

Finally, I collected the number of EPO patents filled out by the applicants of the 4,262 patents in the 5 years, 3 years and 1 year before the sample patent was applied for. This information was used to develop a measure of firm competencies and firm technological specialisation in the years before the innovations were produced.

In the end, my database is composed of 4,262 observations. Each observation is patent for which I gathered information on: a) the innovation; b) the firm that applied for the patent; c) the European region in which the inventors were located while developing the innovation. These variables are listed in Table 1.

\section{[TABLE 1]}

\subsection{Insights from the data}

An important issue when dealing with patent citations is the extent to which patents cite previous inventions patented by the same applicant. Self-citations are an indicator of internal spillovers and highlight the existence of cumulative processes of knowledge creation within the same firm, while citations from other applicants are closer to the more

\footnotetext{
${ }^{3}$ A small share of patents (7.6\%) had more than one applicant. In these cases I collected information on the first applicant of the list.
} 
general idea of spillovers among people belonging to different institutions. There is an issue on whether to include the number of self-citations in an indicator of the importance of the cited patents. On the one hand, large firms tend to cite themselves more compared to small companies because they have larger patent portfolios to cite. This might produce an upward bias in the indicator of the value of patents developed by the large firms. On the other hand, smaller companies might be better at exploiting technological trajectories in specialised niches, which could lead to a high share of self-citations over the total number of citations that they receive.

I have data on forward citations up to 2000. To see whether the inclusion of self-citations makes a difference, Figure 1 shows the distribution of patent citations received by the sample patents in the five years after the application date, with and without self-citations. To limit the truncation problem the descriptive statistics in this Section and in Section 5 will take into account only patents applied in the period 1987-1993. The econometric analysis will use instead the whole 1987-1996 sample, and use time dummies, sectoral dummies and a control variable developed by Hall et al. (2001) as a remedy for the truncation problem and for changes over time and technologies in the rate of patenting and in the number of citations made. The dark blue histograms in Figure 1 include selfcitations; the bright blue histograms are without self-citations.

\section{[FIGURE 1 and 2]}

The distribution of patent citations is skewed. This is consistent with recent works on the use of patent indicators. (See, among the others, Scherer et al., 2000; Scherer and Harhoff, 2000). The number of patent citations excluding self-citations ranges between 0 and 13 , with mean 0.74 and standard deviation 1.34 . About $62 \%$ of all patents receive 0 citation. Only the last quartile and the last decile of the patents receive more than 1 and 2 citations respectively. The top 5\% patents have more than 3 citations. As expected, when self-citations are included, the share of patents with 0 citations drops to $48.8 \%$, and the number of citations ranges between 0 and 19, with mean 1.20 and standard deviation 1.91. In the rest of the paper, due to the ambiguous inclusion of self-citations in an

\footnotetext{
${ }^{4}$ I thank Fabio Pammolli for providing me with data on R\&D and sales for an additional group of companies in my sample.
} 
indicator of the value of patents, I will use the number of citations received by the patents in the five years after the application date depurated of self-citations (hereafter CITS).

Figure 2 looks at the distribution of CITS in biotechnology and traditional chemicals. Patents in traditional chemicals receive a lower number of citations than in biotechnology. The share of patents with 0 citation is $63.2 \%$ in traditional chemicals, and falls to 53.9\% in biotechnology. By contrast, the share of patents in the left-end tail of the distribution is higher in biotech than in traditional chemicals. The average number of forward citations of biotechnology patents is 1.03 compared to 0.69 in traditional chemicals. This difference is statistically significant. As expected, self-citations are more frequent in traditional chemicals than in biotechnology: biotech patents receive 0.35 selfcitations on average compared to 0.48 of traditional chemical patents, and also this difference is statistically significant. This contrast between biotech and traditional chemicals confirms that it is important to control for sectoral characteristics when I will estimate the effect of different firm and regional factors on the propensity of the patents to be cited. This will be done in Section 4 .

As far as the applicants of these patents are concerned, in the period 1987-1993 there are 536 companies in my sample that apply for 3,080 patents. The top 5 companies apply for more than one third of the patents. These companies are Hoechst, Basf, Bayer, Ciba Geigy and Rhone-Poulenc. By contrast, a long tail of companies applies for one or two patents each. Only a small fraction of the companies in the sample (59) produce patents both in biotechnology and traditional chemicals, while 368 companies are active only in traditional chemicals, and 109 only in biotechnology. Table 2 lists the top 20 patents in terms of the maximum number of citations that they received in biotechnology and traditional chemicals in 1987-1993, and lists their applicant firms.

\section{[TABLE 2]}

Twelve companies in the top 20 positions in biotechnology are fairly small companies that develop a limited number of patents only in biotechnology. The other 8 firms are active also in traditional chemicals. Five of these 8 companies are in the top 20 positions in both listings (Hoechst, Ciba Geigy, Zeneca Group, Rhone-Poulenc and Solvay). In traditional chemicals, the top 20 firms are large and well-known companies active in the 
sector for a long time. Moreover, the average number of citations received by the patents applied by companies that innovate only in one sector is not significantly different from the average number of citations of patents applied by companies that are active both in traditional chemicals and in biotechnology.

In order to have some insights on the relationship between the characteristic of the applicant firms and the value of the innovations in biotech and traditional chemicals, Figure 3 groups the patents in three categories (horizontal axis) according to the number of CITS: patents with 0 citations (i.e. the median number of citations), those with 1 citation (i.e. patents in the fourth quartile), and those with 2 citations or more (i.e. patents in the top 10\%). By differentiating between biotech and traditional chemical patents Figure 3 shows the relationship between the average characteristics of firms that produce biotech and traditional chemical patents, and the probability to fall in one of the 3 citation classes. $^{5}$

\section{[FIGURE 3]}

The dark columns are for traditional chemicals. The light ones are for biotechnology. Firm size (SALES) is measured by company sales in millions of 1988 US \$, and it is plotted on the left-end vertical axis (thick histograms). The Figure confirms the expectation that in traditional chemicals the size of the companies is, on average, larger than in biotechnology. Moreover, both in biotechnology and in traditional chemicals there is a negative relationship between the size of the firms and the probability to receive patent citations, that suggests that smaller companies have a higher probability of inventing technological hits.

The average R\&D intensity and the average technological specialisation of companies are plotted on the right-end vertical axis. The firm R\&D intensity ( $R \& D / S A L E S)$ is measured by the ratio between a company R\&D spending and sales in 1988. The smallest histograms on the right of each citation class show the average R\&D intensity of firms in biotechnology and traditional chemicals. The technological specialisation of the companies (TECHSPEC) is measured by the ratio between the number of patents 
developed by the firm in the same technological class of the patent application (i.e. biotechnology, materials, organic chemistry, pharmaceuticals, and polymers) and the total number of EPO patents applied in the 5 years before the patent application. The tall and thin histograms in Figure 3 indicate the average technological specialisation of companies across the 3 citation classes. As expected, not only is innovation in traditional chemicals centred on large incumbent chemical manufacturers while biotech is populated by smaller companies, but the latter firms are on average more R\&D intensive and technological specialised than companies in traditional chemicals. Moreover, there is a positive relationship between the $R \& D$ intensity of firms and the probability of producing highly cited patents in both sectors. In biotechnology, $R \& D / S A L E S$ jumps from $8.5 \%$ in the 0 citation class, to $9.4 \%$ for companies with patents in the top quartile, to $11.0 \%$ for companies with patents in the top $10 \%$ class. In traditional chemicals, $R \& D / S A L E S$ goes from $5.9 \%$, to $5.5 \%$ and $6.6 \%$ in the three citation classes respectively. Differently, the firms' technological specialisation is positively correlated with the probability of developing good patents only in biotechnology (it goes from 0.33 in the bottom 50\% class to 0.40 in the top $10 \%$ citation class), while in traditional chemicals the extent of firms' specialisation does not differ across the 3 citation classes.

To complete the picture I also explored the relationship between the technological characteristics of the regions in which the inventors are located and the value of the innovations in biotech and traditional chemicals. The expectation is that in technologyintensive regions, where innovative activities agglomerate, it is easier to find the specialised and complementary competencies needed in complex R\&D projects. Moreover, since people with complementary expertise are located close to one another, the probability to collaborate increases. My sample patents are invented in 208 NUTS regions: biotech patents are in 110 regions, while traditional chemicals are in 190 regions. Biotech patents, however, are less geographical concentrated than traditional chemical patents: $63 \%$ of all patents in biotechnology are invented in the top quartile regions, and $84 \%$ biotech patents are invented in top 50\% regions. These shares are larger in traditional chemicals: $84 \%$ and $94 \%$ of total patents in traditional chemicals are

\footnotetext{
${ }^{5}$ These average values are calculated at the patent level. Therefore, the 59 firms with
} 
invented in the top 25\% and 50\% regions respectively. The Herfindhal index is 0.020 for biotech, and 0.036 for traditional chemicals. Figures 4 and 5 map the distribution of biotech and traditional chemical patents across the European regions.

\section{[FIGURE 4 and 5]}

The maps are drawn by computing the percentile distribution of the sample patents across the European regions: the smallest symbols are for regions that host a number of patents in the bottom quartile in biotech and traditional chemicals. The size of the symbols increases by moving to the regions in the second quartile, in the third quartile, in the 75\%-90\% interval, and in the top 10\% class (largest circles and triangles). The Figures show that the bulk of biotech and traditional chemical patents are invented approximately in the same countries and groups of regions. More precisely, the top decile regions in biotech and traditional chemicals share 5 regions in common (Darmstadt-Hessen, Switzerland, Ile de France, Berkshire-Becks-Oxfordshire, Surrey-East and West Sussex) that are half of the regions in the top decile in biotechnology. The share of regions in common in the two listings increases in the top quartile regions: two thirds of the regions in the top quartile (15) are both in biotech and traditional chemicals.

To explore further the impact of regions on the probability of the patents to receive citations, I use the geographical indicators provided by the EUROSTAT REGIO database (1999) and the European R\&D database (Reed Elsevier Publisher, 1996). The 1995 stock of higher education laboratories (REGHLABS) and the average number of patents invented in 1987-1996 in all sectors (REGPATS) in the regions are my proxies for the research intensity of the regions. Compared to the number of chemical patents invented in the regions or to the number of chemical laboratories, these indicators are less endogenous with respect to the decision of the firms to locate R\&D activities in a certain region (i.e. the firms themselves do not determine the technological characteristics of the regions). Moreover, while REGHLABS indicates the presence of scientific institutions in the region, REGPATS are the output of more “applied” and technology-related research. ${ }^{6}$ 
The geographical distribution of these variables is skewed. The number of higher education laboratories across regions ranges from 0 to 461, with mean 15 . The top 20 regions in the sample host $50 \%$ of the total number of higher education laboratories located in Europe. The same applies for the number of patents: about $50 \%$ of all patents are invented in the top 18 regions. As expected, the distribution of REGLABS and REGPATS is similar to the distribution of the sample patents across regions (the top 25\% regions host about $74 \%$ of the higher education laboratories and patents invented in all sectors, and this share raises to about $90 \%$ for the top 50\% regions). Like in Figure 3, I calculated the average technological characteristics (REGHLABS and REGPATS over population) of the regions where patents in the 3 citation classes are invented (not shown here). Unfortunately, the results are inconclusive: none of the two measures is correlated with the number of citations received by the patents in biotech and traditional chemicals. This might be due to the fact that the tables do not highlight the net effect of being in a cluster area over the probability of developing valuable innovations in the two sectors. To do so the next section controls for other factors by means of multiple correlation analysis.

\section{Firms vs regions in biotech and traditional chemicals}

To test the combined effect of firm and regional characteristics over the probability of producing technological hits in biotechnology and in traditional chemicals, this section performs a multiple correlation exercise by means of Negative Binomial regressions. As mentioned in Section 2.1, if different models of innovation exist in sectors characterised by different technological regimes, or by different stages of the industry life-cycle the comparison between biotechnology and the rest of the chemical industry is a good candidate to highlight these differences. The test uses the whole 1987-1996 sample that includes 525 biotech patents and 3,737 traditional chemical patents. A novelty of this paper is that it collects data at the patent level. This implies, however, that there is intragroup error correlation for patents developed by the same firms or in the same regions, leading to heteroskedasticity in the regressions. Robust estimators are included in order to produce robust standard errors. 
Three sets of variables are used as regressors. The first one is composed of firm characteristics: characteristics at the level of the firm and characteristics at the level of the R\&D project that led to the innovation. Firm level variables are: $S A L E S$, $R \& D / S A L E S, T E C H C O M P$, and TECHSPEC. A dummy for the missing values of SALES and $R \& D$ is included in the regressions, as well as a dummy for the large non-chemical companies. SALES, a proxy for the size of the firms, is the company sales in 1988 US\$. On the one hand, the size of the firms is expected to have a positive sign on the probability of inventing technological hits because the larger is the firm, the larger is the number of people and firm's units involved in related and coordinated activities. This is expected to produce internal knowledge spillovers. On the other hand, however, large firms might need high coordination efforts and costs in order to produce these spillovers internally. Figure 3 suggests that the latter effect prevails. Once controlling for the size of the firm, R\&D intensity ( $R \& D / S A L E S$ in 1988$)$ is expected to affect positively the production of valuable innovations. This is because the more a firm engages in research activities, the larger the number of projects and people involved in the inventive activity within the same organisation. Moreover, not only does a firm's R\&D activity increase the probability to generate new knowledge internally, but it also contributes to increase a firm’s absorptive capacity to assimilate external knowledge.

I also employ two measures of firms' technological competencies computed by using EPO data. As an indicator of firms' technological competencies in the same sector of the patent application, I constructed the variable TECHSPEC. This is the number of patents applied by the firm in the same technological field as that of the patent application in the 5 years before the patent was applied for. After controlling for the number of patents applied by the firm in the other sectors in the same 5 years period (TECHCOMP), the expectation is that the technological specialisation of the firms (TECHSPEC) is positively correlated with the probability of developing technological hits. This probability is expected to be higher in smaller companies that pursue innovations in specific technological niches. The effect of technological specialisation is thought to be less important for large companies that take advantage of economies of scope in research internal to the firm. For these large companies TECHCOMP is expected to be correlated 
with the R\&D expenditures, and to become statistically insignificant when both variables are included in the regressions.

Firm characteristics at the level of the R\&D project are given by the breadth of the project that led to the patent. This is proxied by three variables: the number of inventors listed in the patent (INVENTORS), a dummy that indicates if the patent is the output of the collaboration among different institutions (MAPPL), and a dummy that indicates if the inventors are co-localised or de-localised at the regional level $(D L O C) .^{7}$ The number of inventors listed in the patent is a proxy for the scale of the research project, while the number of applicants that apply for the patent is a proxy for the breadth of the project that goes beyond the firm boundaries. After controlling for the firm's R\&D intensity, the scale of the research project is expected to positively affect the probability of developing big innovations, both in biotech and in traditional chemicals. This is so also for the collaboration among different institutions that join their resources and capabilities. ${ }^{8}$ The benefit of the collaboration is also expected to compensate the cost and the effort needed to master the collaboration. Finally, the inclusion of the dummy DLOC is based on the idea that the more a research project is complex, interdisciplinary and important for a firm, the more it is mastered internationally with a wide range of competencies that might be located in different units of the firm, in different institutions and in different locations. This would lead to a positive correlation between the probability of a patent being DL and its value. As noted earlier, this dummy also controls for the arbitrary assignment of patents to regions when the inventors are not all located in the same NUTS.

The second set of variables includes regional characteristics. The number of higher education laboratories set up in each region in 1995 (REGHLABS) and the average number of patents invented in each region in the period 1987-1996 (REGPATS) measure the scientific and technological characteristics of the regions. Both in traditional chemicals and in biotechnology the presence of universities and the collaboration with

\footnotetext{
${ }^{7}$ A patent is co-localised if all the inventors are located in the same NUTS region; it is de-localised if at least one inventor is located in a different NUTS region.

${ }^{8}$ MAPPL might underestimate the number of projects developed in collaboration with other organizations. Indeed, there are strategic reasons to apply for individual patents even if the innovations are the output of a collaboration.
} 
the academia has always shown to be of primary importance for the setting up of R\&D laboratories and for the productivity of firms’ R\&D activities (See, for example, Rosenberg, 1998; Zucker, Darby and Armstrong 1998; Arundel and Geuna, 2004). This paper uses REGLABS as a proxy for the presence of scientific institutions located in the area. REGPATS is interpreted as an indicator of the regional technological capabilities. The area of the regions ( $A R E A)$, the population density $(P O P)$ and the economic development measured by the regional per capita GDP (GDP) are used as exogenous controls for the characteristics of the regions. Consistently with the idea of agglomeration economies the expectation is that the population density and the per capita GDP are positively correlated with the probability of developing big innovations, while AREA is expected to have a negative sign.

The third set of data includes other controls. CITSSEC - i.e. the average number of citations made per patent in the same year and technological field of the patent application - is the first of them. This is a very important variable in regressions that deal with patent citations because it creates a benchmark value of citation intensity that controls for the truncation problem and for differences in the citation intensities over time and across sectors that are unrelated with the value of the patents (Hall et al., 2001). Factors like differences in the EPO practices over time and across technological fields, the natural increase in the number of citing patents over time, and the fact that patents applied in different years suffer of different degrees of truncation make it difficult to compare patents on the basis of the number of citations received. CITSSEC serves this purpose by scaling the number of citations received by a patent by the average citation intensity of a group of patents with similar characteristics. The inclusion of CITSSEC also allows me to include in the regressions the whole sample of patents applied in 19871996. $^{9}$

Another control is CITSSC that is the number of citations made by the patent to the past non-patent literature like scientific journals, books, proceedings, etc. It controls for the extent to which a patent is related to basic research. This variable is expected to be 
positively associated with the probability of receiving forward citations because more basic work might be useful for a larger number of future applications. I also include INCYd and APCYd that are dummies for the country of the inventors and the country of the applicant. By including them I will capture the effect of the different regional characteristics independently of the variation across countries. Finally, YEARd (the year in which the patent was applied for) and TECHd (the 5 sectors in which the patent is classified) control for time and technology specific effects that might produce changes in the number of citations. ${ }^{10}$

Table 3 provides the descriptive statistics. Table 4 show the results of the econometric estimates. All the variables are in logs.

[Table 3 and 4]

The first and third column from the right of Table 4 shows the estimated results for biotechnology, while the second and fourth columns from the right shows the results for the traditional branches of the chemical industry. The two specifications for each sector differ only for the inclusion of firm and project characteristics: the first specification does not include TECHSPEC, TECHCOMP and DLOC. The results are robust across the two specifications.

The main result is that technological hits in biotechnology and traditional chemicals are the outcome of very different models of innovation. In traditional chemicals the probability of producing valuable patents depends on firms' internal R\&D effort. The R\&D intensity of the companies and the large scale of the projects affect the probability of inventing highly cited innovations. The elasticity of CITS with respect to R\&D/SALES is 0.134 and 0.151 in the two specifications, and it is statistically significant. These results confirm the expectations drawn from Figures 3 where the firm R\&D intensity was positively correlated with the probability of developing patents in the highest cited patent class. Also the number of inventors (INVENTORS) and the number of institutions

${ }^{9}$ To check for technology-specific citation intensities, CITSSEC uses a 3 digit IPC classification that includes more than 150 chemical and chemical-related classes out of 637 technologies in all fields. 
$(M A P P L)$ that collaborate on a common research project are positively correlated with the probability of producing important patents, suggesting that the probability of developing technological hits is higher when a research project involves large networks of inventors and different organisations.

Once controlling for many factors, SALES, TECHCOMP and DLOC do not add anything to the expected value of the innovations in traditional chemicals. Only the technological specialisation of companies (TECHSPEC) is significantly correlated with CITS, but the sign of this correlation is negative. Rather than the effect of the technological diversification of the companies, the negative sign of TECHSPEC is suggestive of the high propensity to patent in the chemical sector. This is because traditional chemicals is populated by large firms that can apply for patent protection for important innovations and also for less valuable innovations. It is plausible to think that the share of less valuable innovations over the total number of patent applications is smaller in biotechnology. In turn, as the number of patent applications in the specific sector raises, the average quality of the patents decreases, as well as the expected number of CITS. This is confirmed by the fact that firms in traditional chemicals have a higher share of self-citations per patent than firms in biotech, and by the fact that the negative and significant effect of TECHSPEC disappears when self-citations are included in the dependent variable. In this case the negative sign of TECHSPEC is compensated by the fact that firms with larger patent portfolios tend to cite themselves, and this positively affects the expected number of CITS including self-citations.

Unexpectedly, however, the technological characteristics of the regions in which the inventors are located do not raise the probability of developing technological hits in traditional chemicals. This result holds both for the proximity to high education laboratories (REGHLABS) and for the location in technological intensive regions (REGPATS). Since there is a large number of controls in these regressions, this suggests that beyond economies in R\&D internal to the firm, the model of innovation that leads to high expected value patents in traditional chemicals is dominated by large firms that

\footnotetext{
${ }^{10}$ These are time and technology effects that are independent of the changes identified by the variable CITSSEC.
} 
invests heavily in internal $R \& D$ activities and large scale projects, with no role for the spillovers from near-by research laboratories or from the general technological environment in which the research is conducted. ${ }^{11}$

Firm characteristics still matter in biotechnology. Specifically, prior knowledge in developing patents is important for raising the probability of developing successful innovations. However, these competencies must be built in the biotechnology sector. The estimated coefficients of TECHSPEC and TECHCOMP are 0.264 and -0.196 , and are statistically significant. In other words, technological specialisation matters for producing big biotech innovations. The expected value of innovations rises also when firms carry out R\&D projects in collaboration with other institutions. The coefficient of MAPPL is positive (0.504 and 0.539$)$ and it is statistically significant in both specifications.

Moreover, consistently with the more basic nature of biotechnology research compared to traditional chemicals, also CITSSC is positive and statistically significant in biotechnology.

But what really distinguishes the biotech from the traditional chemical model is the importance of the regions. More specifically, the richness of the technological environment in which the research is carried out influences the probability of developing technological hits in biotechnology: after including extensive controls for the firms, the projects and the regions, the net effect of REGPATS is positive (0.303 and 0.323$)$ and statistically significant in both specifications. Surprisingly, however, the expectation that the geographical proximity to university laboratories is correlated to the probability of inventing important innovations in biotechnology is not confirmed. This is probably due to the fact that the number of patents invented in a region proxies for the general scientific and technological environment in which the inventors are located, and measures the scale and the productivity of the research activities carried out by both public and private institutions in the area. These results also suggest that the "regional" effect is a "real" effect: although biotech and traditional chemical patents are produced

\footnotetext{
${ }^{11}$ The regional characteristics are also jointly insignificant. By performing a Likelihood Ratio test, the unrestricted model in Table 4 is checked against a restricted model with $R E G-H L A B S=R E G-P A T S=G D P=P O P=A R E A=0$. With 5 degrees of freedom the null hypothesis is not rejected.
} 
under the same geographical conditions (See Figures 4 and 5), geography affects the probability of developing valuable inventions only in biotechnology. ${ }^{12}$

\section{Some more evidence}

So far the empirical results show that the positive effect of being an $R \& D$ intensive firm with large R\&D projects dominates over any other factors for developing technological hits in traditional chemicals: spillovers are bounded within the same R\&D intensive firm, with only a positive effect of setting up R\&D collaborations with other organisations. By contrast, in biotech, technological specialised firms located in technological intensive regions are likely to produce high expected value innovations.

This section adds empirical evidence to test the importance of the geographical proximity of the inventors to external sources of knowledge in biotech compared to traditional chemicals. Citations to past patents are used in the literature as indicators of knowledge spillovers from the cited to the citing patent (see, for example, Jaffe et al., 1993). Based on this idea I considered each pair of citing and cited patents in my sample: the citing patents are the 4,262 patents described in Section 3.1; the number of cited patents is 7,304 , i.e. patents used as prior art to develop the 4,262 innovations. I use the zip-code contained in the addresses of the inventors of the cited patents to assign them to the specific NUTS region in which they are invented. This allows me to identify three classes of cited patents: 1) patents invented in the same NUTS region of the citing patent. These are the "local citations"; 2) patents invented in different regions but in the same country of the citing patent, i.e. "national citations”; 3) patents invented entirely in different

\footnotetext{
${ }^{12}$ I alternatively included in the regressions the number of chemical laboratories, the number of private laboratories and the total number of laboratories in the regions in place of REGHLABS, and the number of chemical patents invented in the regions in place of REGPATS. The results are not significantly different from those shown in Table 4: the number of chemical patents invented in the regions is positive and significant, while the number of laboratories of any type does not affect CITS. The results in Table 4 are also robust to the inclusion of self-citations in the dependent variable, and to the use of patent citations in all years after the application date up to 2000. The empirical estimates are available from the author.
} 
countries "international citations". ${ }^{13}$ I also identified the self-citations in the sample (i.e. citations to patents applied by the very same applicant of the citing patent): they account for 2,171 patents and tend to be located in the same area and firm of the citing patents. The remaining 5,133 cited patents are distributed as follows: 378 are "local citations"; 660 are "national citations"; 4,095 are "international citations”. Some interesting facts emerge from the data. First, the overall share of "local citations" is small (7.4\%) suggesting that geographical proximity has a limited importance on the probability of a patent to be used as prior knowledge. Second, proximity is relatively more important in biotechnology than in traditional chemicals. To see this I calculated the share of "local citations” in biotechnology and in traditional chemicals. (See Hicks and Buchanan, 2003 for a similar exercise). This is given by the ratio $S=\frac{\sum_{i} c_{i l}}{\sum_{i} c_{i}}$, where $i$ denotes the patent, $c_{i l}$ is the number of local citations made by each patent in the sample to previous patents invented in the same NUTS region of the citing patent, and $c_{i}$ is the total number of citations made by each patent in the sample. In the same fashion I calculated the shares of national, international and self-citations made by the sample patents to previous EPO patents. Table 5 shows these ratios.

\section{[TABLE 5]}

The first row in Table 5 confirms that the probability of a patent to be cited if it is developed in the same region of the citing patent is higher in biotech than in traditional chemicals: the share of local citations in biotechnology is $7.6 \%$ compared to $4.8 \%$ in traditional chemicals. This is consistent with the econometric estimates: proximity to external sources of knowledge is relatively more important in biotechnology than in the traditional branches of the chemical industry. The results of the regressions also say that

\footnotetext{
${ }^{13}$ It is a "local citation" when at least one inventor in the cited and citing patent is located in the same region. If none of the inventors are located in the same region, but at least one inventor is located in the same country of the citing patent, it is a "national citation". If all the inventors of the citing and cited patents are located in different countries, it is an "international citation".
} 
this proximity produces a positive effect on the expected value of the innovations in biotech.

Third, it is interesting that the share of international citations is large in both sectors(69.7 in biotechnology and 53.9\% in traditional chemicals) suggesting that international linkages are a very important source of knowledge in developing innovations. Again, however, international citations are more frequent in biotech than in traditional chemicals. This suggests that the process of innovation in biotechnology relies either on international sources of knowledge, or on local linkages. Finally, it is worth noticing that the share of self-citations is higher in traditional chemicals than in biotechnology $(31.9 \%$ vs. 15.4\%): one third of the citations made by traditional chemical patents are to patents developed by the very same firm that developed the citing patents. This is consistent with the econometric results about the importance of spillovers internal to the firm in traditional chemicals.

\section{Conclusions}

Firm competencies and regional characteristics are often discussed in the literature as different sources of firms' competitive advantages. This paper compares the firm and the geographical cluster as organisation modes for producing valuable innovations. It estimates how much of the value of an innovation depends on the characteristics of the organisation to which the inventors are affiliated, and how much it is affected by the characteristics of the location in which it is invented. To do so it uses information on 4,262 European patents in five chemical sectors applied for in 1987-1996, and links these data to other sources of information on firm and regional characteristics. The geographical unit of analysis is the European regions according to the NUTS classification (Nomenclature des Unités Territoriales Statistiques) at the third and second level of disaggregation.

The econometric results suggest that there is a differential effect of the characteristics of the location in which the research is conducted in biotechnology compared to traditional chemicals. In biotechnology, a new and science-intensive sector, big innovations are 
more likely to be produced by firms that are technologically specialised in that sector. Knowledge spillovers from being located in a technological intensive region help in raising the probability of inventing technological hits. This model of innovation has only one element in common with the traditional model: the importance of establishing research collaborations with other firms o institutions. Differently, in the traditional branches of the chemical sector, large established companies that invest heavily in internal $R \& D$ activities and engage in large $R \& D$ projects have a higher probability of producing big innovations. Economies of scale in research are internal to the firm, while geographically localised spillovers do not affect the probability of inventing technological hits.

There is an alternative interpretation of the positive effect of regional characteristics in biotech. Consistently with Zucker, Darby and Armstrong (1998), Zucker, Darby, and Brewer (1998) and Klepper and Sleeper (2002) there might be regions that are better at doing some kind of relevant research because of the presence of some top universities or some high-tech companies. These regions spawn a large number of $R \& D$ performing startups founded by the personnel employed in the top organisations, and produce a large numbers of patents together with high citation intensities in the areas. This interpretation is still consistent with the idea of spillovers, although such spillovers are not produced directly by the technological environment as proxied by the number of higher education laboratories or the number of patents invented in the region, but come from the initial technological characteristics of the regions in which these firms are located. Still, this paper shows that this would happen in biotechnology more than in traditional chemicals.

\section{References}

Aftalion, F., 1991. A History of the International Chemical Industry, University of Pennsylvania Press, Philadelphia (PA)

Arora, A., Fosfuri, A., Gambardella, A., 2001. Markets for Technology, MIT Press, Cambridge (MA)

Arundel, A., Geuna, A., 2004. Proximity and the Use of Pulic Science by Innovative European Firms. Economics of Innovation and New Technology, forthcoming 
Audretsch, D.B., Feldman, M.P., 1996. Knowledge Spillovers and the Geography of Innovation and Production, American Economic Review, 86 (3), 630-640

Breschi, S., 1999. Spatial Patterns of Innovation: Evidence from Patent Data, in: Gambardella, A., Malerba F., (Eds.), The Organisation of Innovative Activity in Europe, Cambridge University Press, Cambridge (MA)

Caniels, M., 1999. Regional Growth Differentials. The Impact of Locally Bounded Knowledge Spillovers, Ph.D dissertation, University of Maastricht.

Christensen, C. M., 1997. The Innovator's Dilemma, When New Technologies Cause Great Firms to Fail, Harvard Business School Press, Boston (MA)

de Solla Price, D.J., Beaver, D.B., 1966. Collaboration in an invisible college, American Psychologist 21 (1), 1011-1018.

Dosi, G., Freeman, C., Nelson, R., Silverberg, G., Soete, L., 1988. Technical Change and Economic Theory, F. Pinter, London

Griliches, Z., 1990. Patent Statistics as Economic Indicators: A Survey, Journal of Economic Literature, vol. XXVIII, 1661-1707

Griliches, Z., Pakes, A., Hall, B., 1987. The Value of Patents as Indicators of Inventive Activity, in: Dasgupta, P., Stoneman, P., (Eds.), Economic Policy and Technological Performance, Cambridge University Press, Cambridge (MA)

Hall, B., Jaffe, A., Trajtenberg, M., 2000. Market Value and Patent Citations: A First Look, NBER Working Paper No. 7741

Hall, B., Jaffe, A., Trajtenberg, M., 2001. The NBER Patent Citations Data File: Lessons, Insights and Methodological Tools, NBER working paper No. 8498

Harhoff, D., Scherer, F., Vopel, K., 1999. Citations, Family Size, Oppositions and the Value of Patent Rights: Evidence from Germany, mimeo (February)

Hicks, D., Buchanan L., 2003. Serial innovators and the markets for technology, paper prepared for the ASEAT/Institute of Innovation research Conference, Manchester UK, mimeo (April)

Jaffe, A., 1986. Technological Opportunity and Spillovers of R\&D: Evidence from Firms’ Patents, Profits and Market Value, American Economic Review 76(5), 984-1001

Jaffe, A., Trajtenberg, M., Henderson R., 1993. Geographic Localization of Knowledge Spillovers as Evidenced by Patent Citations, Quarterly Journal of Economics, 63(3), 577598 
Klepper, S., 1996. Entry, Exit, Growth, and Innovation over the ProductLifeCycle, American Economic Review, 86(4), 562-583

Klepper, S., 2001. Employee startups in high tech industries, Industrial and Corporate Change, 10, 639-74

Klepper, S., Sleeper S., 2002. Entry by Spinoffs, mimeo

Lanjouw, J.O., Schankerman, M., 2004. Patent Quality and Research Productivity: Measuring Innovation with Multiple Indicators, Economic Journal, forthcoming

Levinthal, D.A., March, J.G., 1993. The Myopia of Learning, Strategic Management Journal, 14, 95-112

Merton, R.K., 1973, The sociology of science, The University of Chicago Press, Chicago.

Narin, F., Withlow, E.S., 1990. Measurement of scientific cooperation and coauthorship in CEC-related areas of science, Vol. 1 Commission of the European Communities (EUR 12900 EN), Brussels

Nelson, R., 1995., Recent Evolutionary Theorizing about Economic Change, Journal of Economic Literature, 33, 48-90

Nelson, R., Winter, S., 1982. An Evolutionary Theory of Economic Change, Harvard University Press, Cambridge (MA)

Orsenigo, L., 1989. The Emergence of Biotechnology: Institutions and Markets in Industrial Innovations, F. Pinter, London

Patel, P., Pavitt, K., 1997. The Technological Competencies of the World's Largest Firms: Complex and Path Dependent, but not Much Variety, Research Policy, 26, 141-56

Pavitt K., 1987. On the nature of technology, University of Sussex, SPRU, Brighton

Powell, W., Koput, K., Smith-Doerr, L., 1996. Interorganisational collaboration and the locus of innovation: Networks of learning in biotechnology, Administrative Science Quarterly, 41 (1), 116-145

Rosenberg, N., 1998. Technological Change in Chemicals: the Role of UniversityIndustry Relations, in: Arora, A., Landau, R., Rosenberg, N., (Eds.), Chemicals and Long-term Economic Growth: Insights from the Chemical Industry, John Wiley \& Sons, New York 
Scherer, F., Harhoff, D., Kukies, J., 2000. Uncertainty and the Size Distribution of Rewards from Technological Innovation, Journal of Evolutionary Economics, 10, 175200

Scherer, F., Harhoff, D., 2000. Technology Policy for a World of Skew-distributed Outcomes, Research Policy, 29, 559-566

Swann, P., Prevezer, M., Stout D. (Eds.), 1998. The Dynamics of Industrial Clustering. International Comparisons in Computing and Biotechnology, Oxford University Press, Oxford UK

Teece, D.J., Pisano, G., Shuen, A., 1997. Dynamic Capabilities and Strategic Management, in Strategic Management Journal, 18, 509-534

Trajtenberg, M., 1990. A Penny for Your Quotes: Patent Citations and the Value of Innovation, Rand Journal of Economics, 21(1), 172-87

Verspagen B., 1997. European Regional Clubs: Do They Exist and Where Are They Heading? On Economic and Technological Differences between European Regions, in: Adams J., Pigliaru F. (Eds.), Economic Growth and Change: National and Regional Patterns of Convergence and Divergence, Edward Elgar, Cheltenham

Zucker, L., Darby, M., Armstrong, J., 1998. Geographically localized knowledge: Spillovers or markets?, Economic Inquiry, 36, January, 65-86

Zucker, L., Darby, M., Brewer M., 1998. Intellectual human capital and the birth of U.S. biotechnology enterprises, The American Economic Review, 88 (1), 290-306 


\title{
FIGURES AND TABLES
}

Table 1: List of variables

\author{
Firm characteristics
}

\begin{tabular}{|c|c|}
\hline CITS & $\begin{array}{l}\text { Number of citations received by the patent in the } 5 \text { years after the } \\
\text { application date, excluding self-citations }\end{array}$ \\
\hline SALES & Company sales in 1988 (Millions of 1988 US\$) \\
\hline$R \& D / S A L E S$ & Company R\&D spending over sales in 1988 \\
\hline TECHSPEC & $\begin{array}{l}\text { Number of EPO patents applied by the firm in the } 5 \text { years before the patent } \\
\text { application in the same technological field (biotech, materials, organic } \\
\text { chemistry, pharmaceuticals, and polymers) }\end{array}$ \\
\hline ТЕСНСОМР & $\begin{array}{l}\text { Number of EPO patents applied by the firm in the } 5 \text { years before the patent } \\
\text { application in other technological classes than the one of the sample patent }\end{array}$ \\
\hline INVENTORS & Number of inventors that collaborate to develop the innovation \\
\hline$D L O C$ & $\begin{array}{l}\text { Dummy. It takes the value } 1 \text { if the inventors listed in the patent are located } \\
\text { in the same region; } 0 \text { otherwise }\end{array}$ \\
\hline MAPPL & Dummy. It takes the value 1 if there are multiple applicants; 0 otherwise \\
\hline CITSSC & Number of citations made by the patent to the past scientific literature \\
\hline NOCHEM & Dummy for non chemical companies \\
\hline MISSING & Dummy for missing values on $S A L E S$ and $R \& D$ \\
\hline \multicolumn{2}{|r|}{ Regional characteristics } \\
\hline REGHLABS & $\begin{array}{l}\text { Number of higher education laboratories located in the region (stock in } \\
\text { 1995) }\end{array}$ \\
\hline REGPATS & Number of patents invented in the regions (units - average 1987-1996) \\
\hline$G D P$ & $\begin{array}{l}\text { Regional per capita Gross Domestic Product in millions of purchasing power } \\
\text { parity and corrected for inflation (average 1987-1996) }\end{array}$ \\
\hline POP & Population density of the region (thousands - average 1987-1996) \\
\hline AREA & Area of the region in $\mathrm{Km}^{2}$ \\
\hline
\end{tabular}

Citation intensity of patents applied in the same cohort of the patent application

CITSSEC - i.e. average number of citations received by the patents applied in the same year and in the same technological field of the patent application (3 digit IPC classes).

INVCY Dummy for the country of the inventors (At, Be, Ch, De, Dk, Es, Fi, Fr, Gr, Ie, It, Lu, Nl, Se, Uk)

APPLCY Dummy for the country of the applicant firm (At, Be, Ch, De, Dk, Es, Fi, Fr, Gr, Ie, It, Lu, Nl, Se, Uk, Jp, Us, Others)

YEAR Dummy for the application date (1987-1996)

SECTOR Dummy for the sector in which the patent is classified: biotechnology, materials, organic chemistry, pharmaceuticals, and polymers 
Figure 1. Distribution of CITS - number of citations received by the patents in the 5 years after the application date, excluding and including self-citations

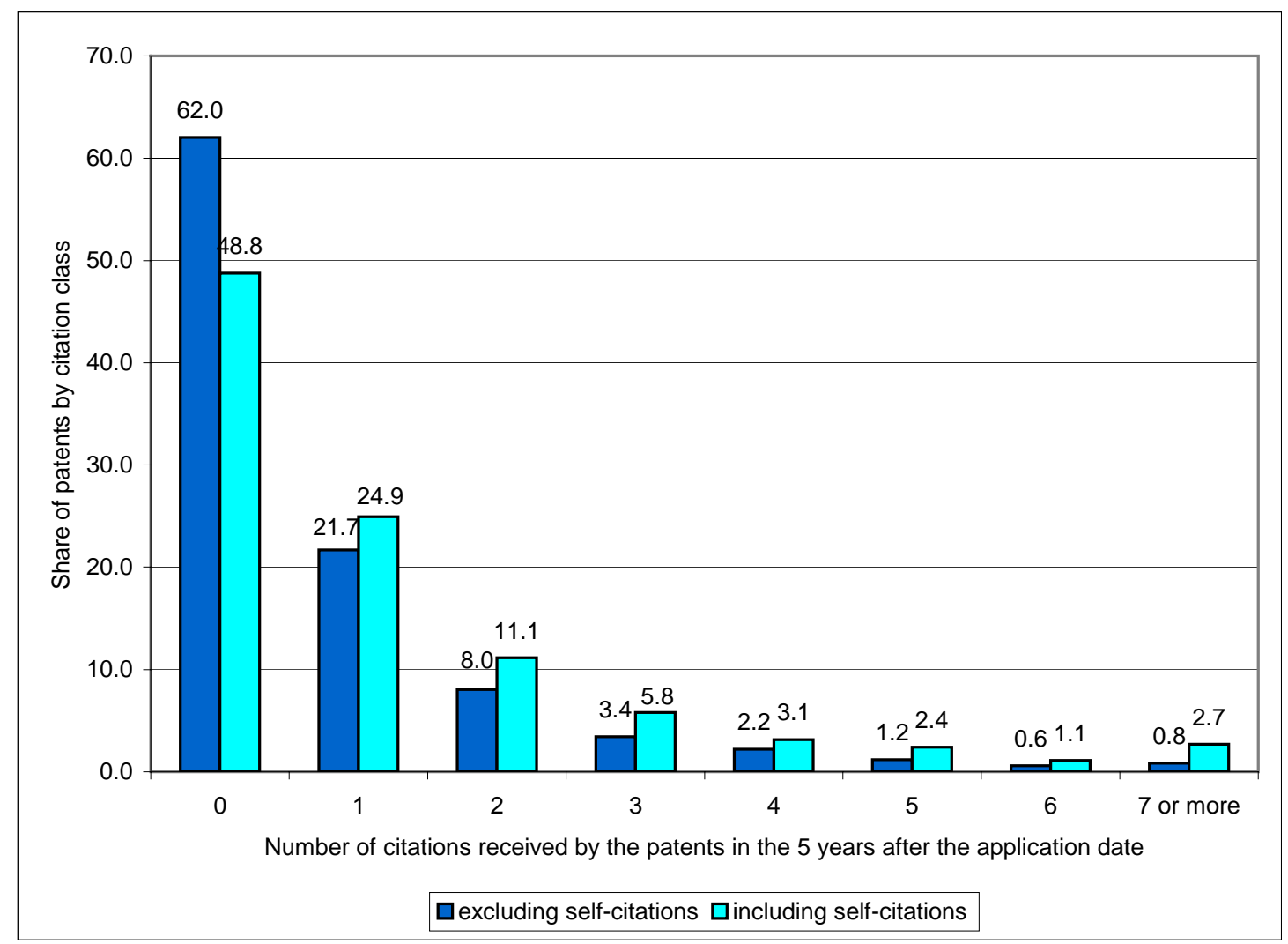

Source: Elaboration from the EPO data, 1987-1993. Sample: 3,080 patents. 
Figure 2. Distribution of CITS - number of citations received by the patents in the 5 years after the application date: biotechnology and traditional chemicals

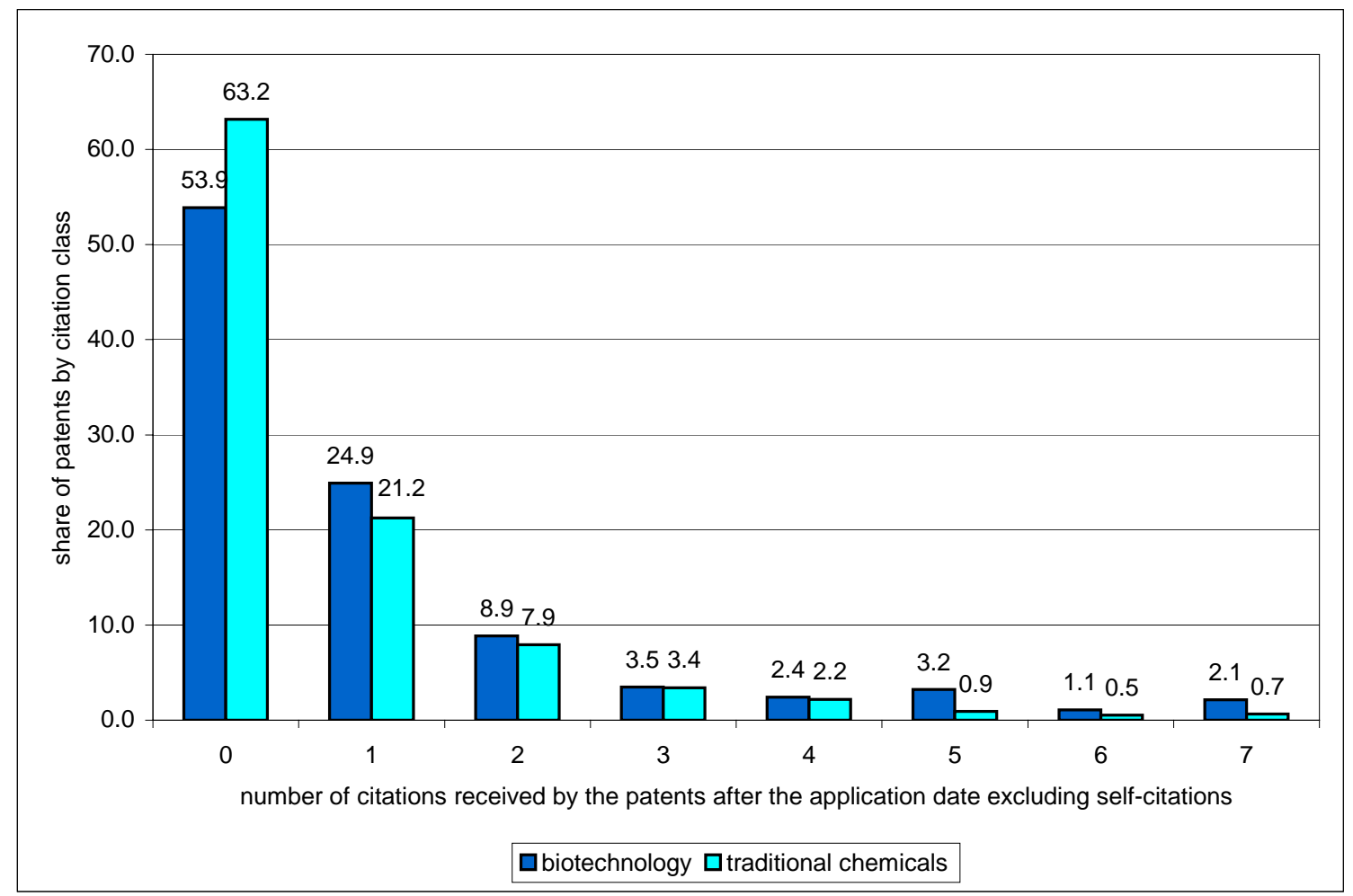

Source: Elaboration from the EPO data, 1987-1993. Sample: 3,080 patents. 
Table 2: Top twenty patents in terms of patent citations

\begin{tabular}{lrlr}
\hline \multicolumn{1}{c}{ Biotechnology } & \multicolumn{2}{c}{ Traditional chemicals } \\
\hline Applicant & $\begin{array}{r}\text { Af } \\
\text { citations }\end{array}$ & & $\begin{array}{c}\text { Applicant } \\
\text { citations }\end{array}$ \\
\hline B.A.T. Industries PLC & 11 & Zeneca Group PLC & 13 \\
Silica Apparatebau GmbH & 10 & Targor GmbH & 11 \\
Imcera Group Inc. & 9 & Bayer AG & 10 \\
Ciba Geigy AG & 8 & Glaxo Wellcome PLC & 10 \\
Hoechst AG & 8 & Guerbet S.A. & 10 \\
Plant Genetic Systems N.V. & 7 & Basf AG & 9 \\
Zeneca Group PLC & 7 & C.H. Boehringer Sohn & 9 \\
E.I. Du Pont de Nemours & 6 & Rhone-Poulenc S.A. & 9 \\
Max-Planck-Gesellschaft & 6 & Dr. Zambeletti S.p.A. & 8 \\
Transgene S.A. & 6 & Hafslund Nycomed A/S & 8 \\
Akzo Nobel N.V. & 5 & Solvay S.A. & 8 \\
Biomerieux Alliance S.A. & 5 & Warner-Lambert Co. & 8 \\
Got-a-Gene AB & 5 & Ciba Geigy AG & 7 \\
ISIS Pharmaceuticals INC. & 5 & Monsanto Co. & 7 \\
Merial & 5 & Polifarma S.p.A. & 7 \\
Rhone-Poulenc S.A. & 5 & Schering AG & 7 \\
Royal Gist-Brocades N.V. & 5 & The Procter \& Gamble Co. \\
Sclavo S.p.A. & 5 & Vectorpharma International SpA & 7 \\
Solvay S.A. & 5 & Colgate Palmolive Co. & 6 \\
Amersham International PLC & 4 & Hoechst AG & 6 \\
\hline
\end{tabular}

Source: Elaboration from the EPO data, 1987-1993. Sample: 3,080 patents. 
Figure 3: Average characteristics of firms with patents in biotechnology and traditional chemicals: Size (Mean of SALES), R\&D intensity (Mean of R\&D/SALES) and technological specialisation (mean of and TECHSPEC) of firms.

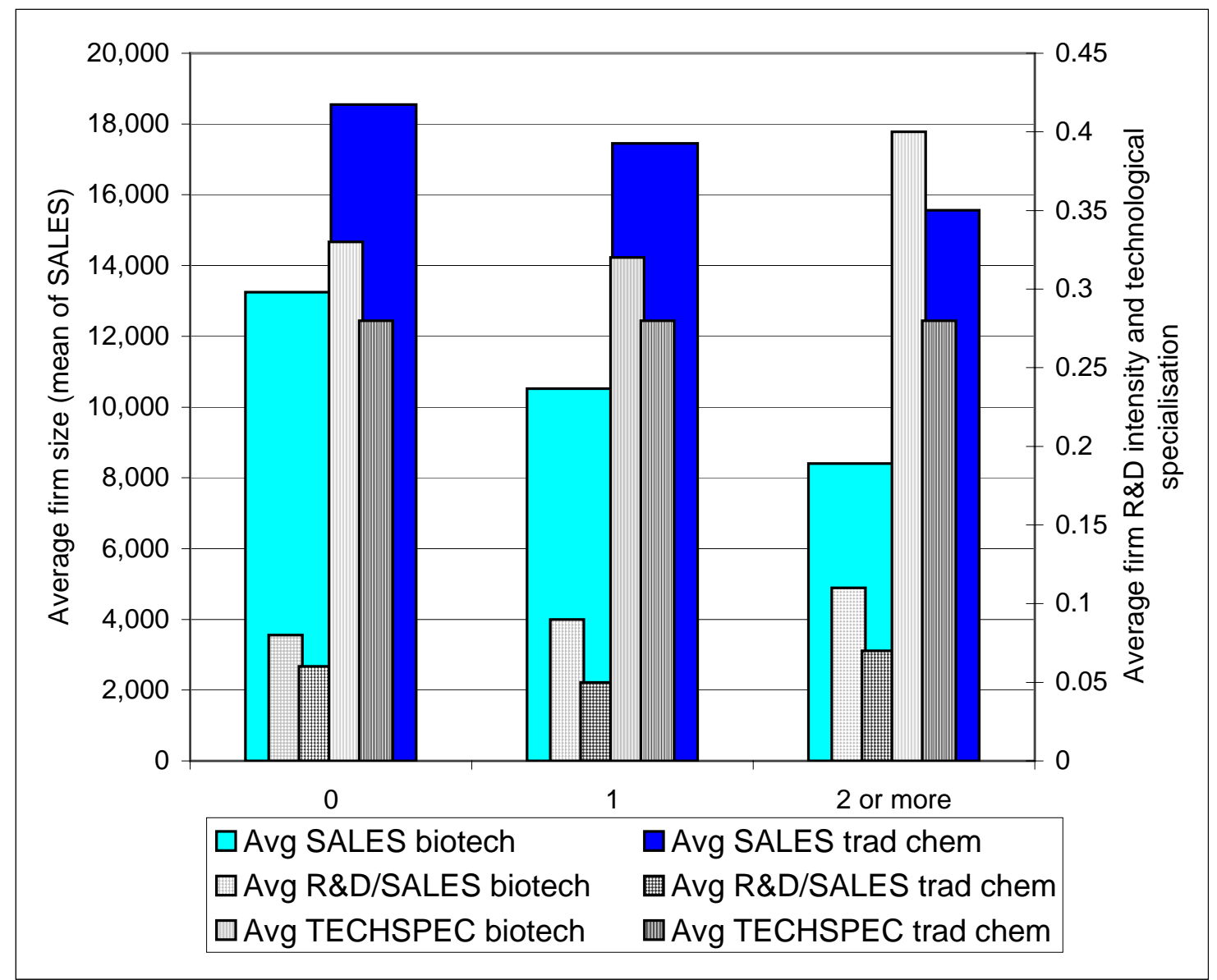

Source: Elaboration from the EPO, Aftalion and Compustat data, 1987-1993. Sample: 2,570 patents for SALES; 2,517 patents for R\&D/SALES; 3,057 patents for TECHSPEC. 
Figure 4: Geographical distribution of biotech patents

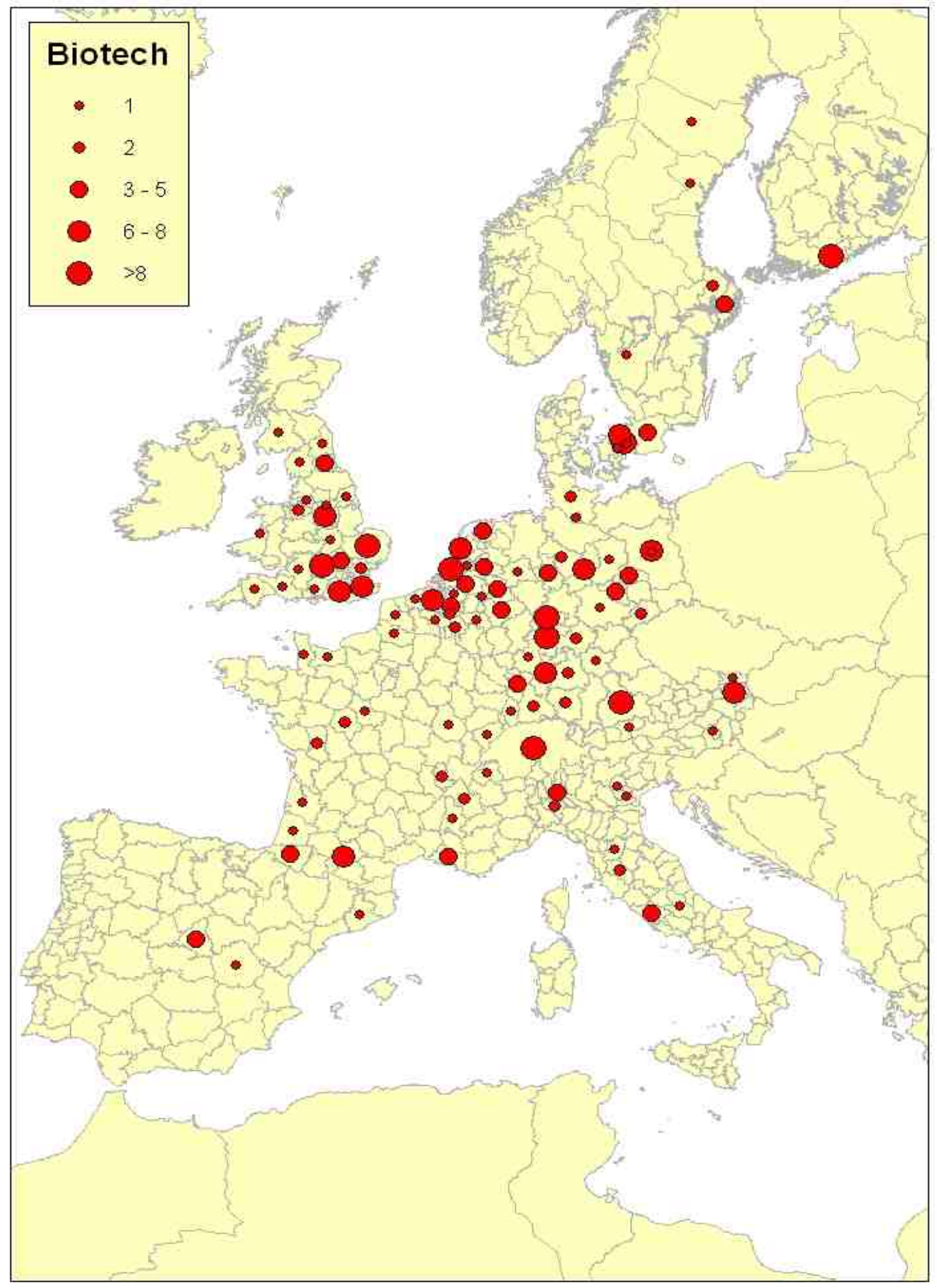


Figure 5: Geographical distribution of traditional chemical patents

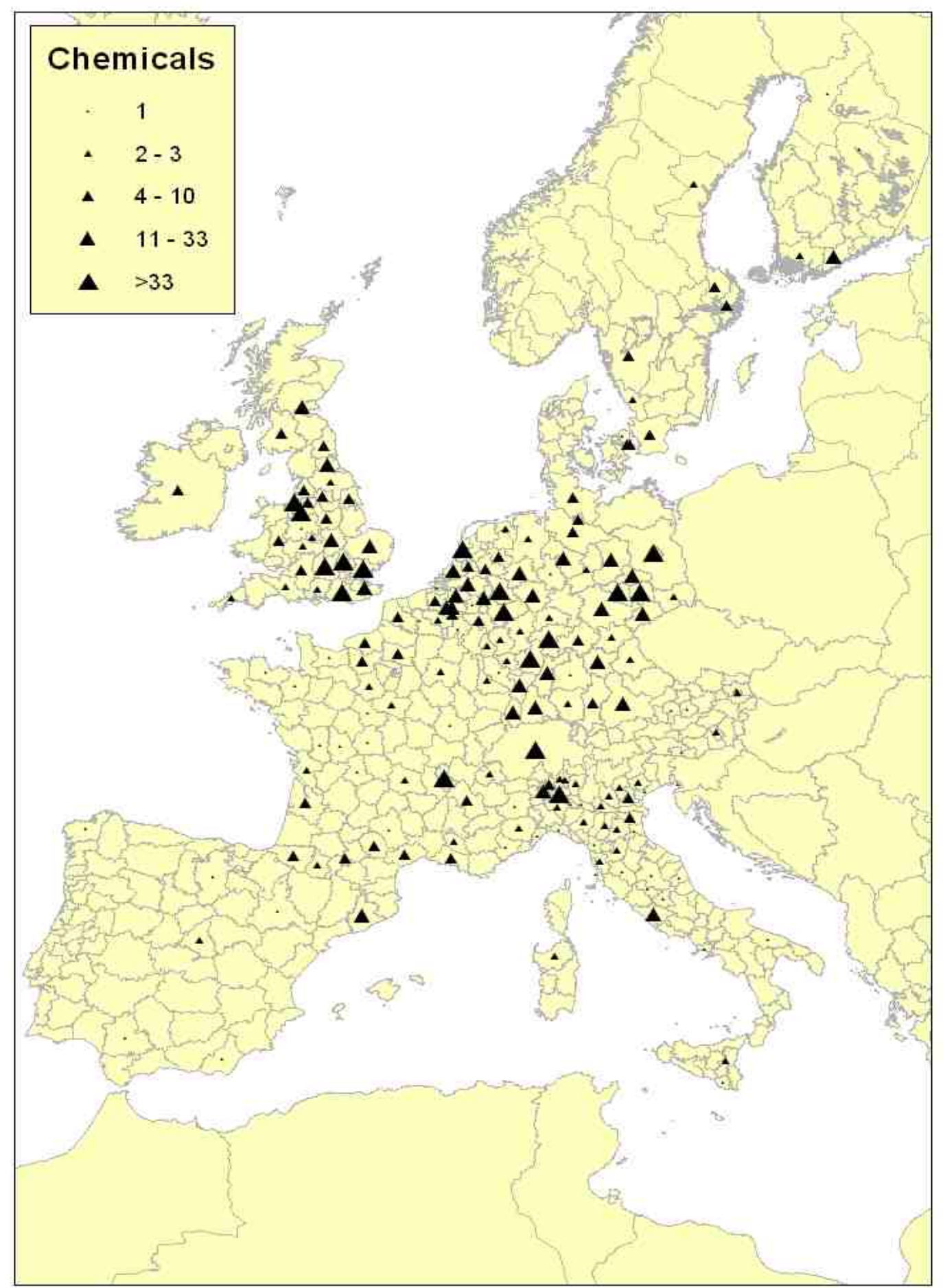


Table 3: Descriptive statistics. Traditional chemicals and biotechnology (biotechnology in italics)

\begin{tabular}{|c|c|c|c|c|}
\hline Variable & Mean & $\begin{array}{l}\text { Standard } \\
\text { Deviation }\end{array}$ & Minimum & Maximum \\
\hline \multicolumn{5}{|c|}{ Firm characteristics } \\
\hline CITS & $\begin{array}{l}0.58 \\
0.84\end{array}$ & $\begin{array}{l}1.16 \\
1.54\end{array}$ & $\begin{array}{l}0 \\
0\end{array}$ & $\begin{array}{l}13 \\
11\end{array}$ \\
\hline SALES & $\begin{array}{l}17,574 \\
10,889\end{array}$ & $\begin{array}{l}14,895 \\
13,575\end{array}$ & $\begin{array}{l}4 \\
4\end{array}$ & $\begin{array}{l}87,542 \\
79,643\end{array}$ \\
\hline$R \& D / S A L E S$ & $\begin{array}{l}0.06 \\
0.09\end{array}$ & $\begin{array}{l}0.10 \\
0.11\end{array}$ & $\begin{array}{l}0.002 \\
0.002\end{array}$ & $\begin{array}{l}3.12 \\
0.85\end{array}$ \\
\hline TECHSPEC & $\begin{array}{c}307 \\
44\end{array}$ & $\begin{array}{c}351 \\
59\end{array}$ & $\begin{array}{l}0 \\
0\end{array}$ & $\begin{array}{c}1,230 \\
252\end{array}$ \\
\hline ТЕСНСОМР & $\begin{array}{c}1,073 \\
506\end{array}$ & $\begin{array}{c}1,174 \\
971\end{array}$ & $\begin{array}{l}0 \\
0\end{array}$ & $\begin{array}{l}6,264 \\
4,502\end{array}$ \\
\hline INVENTORS & $\begin{array}{l}3.19 \\
3.15\end{array}$ & $\begin{array}{l}1.85 \\
1.84\end{array}$ & $\begin{array}{l}1 \\
1\end{array}$ & $\begin{array}{l}16 \\
14\end{array}$ \\
\hline$D L O C$ & $\begin{array}{l}0.62 \\
0.59\end{array}$ & $\begin{array}{l}0.49 \\
0.49\end{array}$ & $\begin{array}{l}0 \\
0\end{array}$ & $\begin{array}{l}1 \\
1\end{array}$ \\
\hline MAPPL & $\begin{array}{l}0.06 \\
0.10\end{array}$ & $\begin{array}{l}0.23 \\
0.31\end{array}$ & $\begin{array}{l}0 \\
0\end{array}$ & $\begin{array}{l}1 \\
1\end{array}$ \\
\hline \multicolumn{5}{|c|}{ Regional characteristics } \\
\hline REGHLABS & $\begin{array}{l}46 \\
45\end{array}$ & $\begin{array}{l}71 \\
69\end{array}$ & $\begin{array}{l}0 \\
0\end{array}$ & $\begin{array}{l}461 \\
461\end{array}$ \\
\hline REGPATS & $\begin{array}{l}610 \\
467\end{array}$ & $\begin{array}{l}609 \\
605\end{array}$ & $\begin{array}{c}0.8 \\
0\end{array}$ & $\begin{array}{l}2,263 \\
2,263\end{array}$ \\
\hline$G D P$ & $\begin{array}{l}16.9 \\
17.1\end{array}$ & $\begin{array}{l}4.4 \\
4.3\end{array}$ & $\begin{array}{l}7.4 \\
7.6\end{array}$ & $\begin{array}{l}27.5 \\
27.5\end{array}$ \\
\hline POP & $\begin{array}{l}0.70 \\
0.67\end{array}$ & $\begin{array}{l}0.87 \\
0.92\end{array}$ & $\begin{array}{c}0.01 \\
0.005\end{array}$ & $\begin{array}{l}5.93 \\
5.73\end{array}$ \\
\hline$A R E A$ & $\begin{array}{l}6,207 \\
6,499\end{array}$ & $\begin{array}{l}3,981 \\
5,574\end{array}$ & $\begin{array}{l}97 \\
97\end{array}$ & $\begin{array}{l}35,291 \\
55,401\end{array}$ \\
\hline \multicolumn{5}{|c|}{ Other controls } \\
\hline CITSSC & $\begin{array}{l}1.16 \\
3.14\end{array}$ & $\begin{array}{l}1.8 \\
2.7\end{array}$ & $\begin{array}{l}0 \\
0\end{array}$ & $\begin{array}{l}24 \\
17\end{array}$ \\
\hline CITSSEC & $\begin{array}{l}1.44 \\
1.70\end{array}$ & $\begin{array}{l}0.58 \\
0.67\end{array}$ & $\begin{array}{l}0.13 \\
0.07\end{array}$ & $\begin{array}{l}4.02 \\
3.49\end{array}$ \\
\hline
\end{tabular}

Number of observations: 525 biotech patents and 3,737 traditional chemical patents 
Table 4: Estimates of Negative Binomial regressions. Dependent variable: number of citations received by the patent in the 5 years after the application date excluding selfcitations (CITS)

\begin{tabular}{|c|c|c|c|c|}
\hline & Trad. Chemicals & Biotechnology & Trad. Chemicals & Biotechnology \\
\hline \multicolumn{5}{|c|}{ Firm characteristics } \\
\hline SALES & $\begin{array}{c}-0.002 \\
(0.027)\end{array}$ & $\begin{array}{c}-0.035 \\
(0.056)\end{array}$ & $\begin{array}{c}0.019 \\
(0.031)\end{array}$ & $\begin{array}{c}0.037 \\
(0.065)\end{array}$ \\
\hline$R \& D / S A L E S$ & $\begin{array}{c}0.134 \\
(0.043)\end{array}$ & $\begin{array}{c}-0.018 \\
(0.116)\end{array}$ & $\begin{array}{c}0.151 \\
(0.043)\end{array}$ & $\begin{array}{l}-0.079 \\
(0.124)\end{array}$ \\
\hline TECHSPEC & - & - & $\begin{array}{c}-0.093 \\
(0.040)\end{array}$ & $\begin{array}{c}0.264 \\
(0.108)\end{array}$ \\
\hline ТЕСНСОМР & - & - & $\begin{array}{c}0.031 \\
(0.037)\end{array}$ & $\begin{array}{c}-0.196 \\
(0.074)\end{array}$ \\
\hline INVENTORS & $\begin{array}{c}0.183 \\
(0.062)\end{array}$ & $\begin{array}{c}0.125 \\
(0.119)\end{array}$ & $\begin{array}{c}0.200 \\
(0.066)\end{array}$ & $\begin{array}{c}0.154 \\
(0.129)\end{array}$ \\
\hline$D L O C$ & - & - & $\begin{array}{c}0.033 \\
(0.072)\end{array}$ & $\begin{array}{c}0.169 \\
(0.168)\end{array}$ \\
\hline MAPPL & $\begin{array}{c}0.271 \\
(0.133)\end{array}$ & $\begin{array}{c}0.504 \\
(0.229)\end{array}$ & $\begin{array}{c}0.278 \\
(0.131)\end{array}$ & $\begin{array}{c}0.539 \\
(0.232)\end{array}$ \\
\hline \multicolumn{5}{|c|}{ Regional characteristics } \\
\hline REGHLABS & $\begin{array}{c}0.054 \\
(0.041)\end{array}$ & $\begin{array}{c}-0.061 \\
(0.081)\end{array}$ & $\begin{array}{c}0.052 \\
(0.042)\end{array}$ & $\begin{array}{c}-0.076 \\
(0.081)\end{array}$ \\
\hline REGPATS & $\begin{array}{l}-0.025 \\
(0.058)\end{array}$ & $\begin{array}{c}0.303 \\
(0.151)\end{array}$ & $\begin{array}{c}-0.021 \\
(0.059)\end{array}$ & $\begin{array}{c}0.323 \\
(0.154)\end{array}$ \\
\hline$G D P$ & $\begin{array}{c}-0.220 \\
(0.236)\end{array}$ & $\begin{array}{c}-0.474 \\
(0.526)\end{array}$ & $\begin{array}{c}-0.231 \\
(0.238)\end{array}$ & $\begin{array}{c}-0.373 \\
(0.550)\end{array}$ \\
\hline POP & $\begin{array}{c}0.036 \\
(0.089)\end{array}$ & $\begin{array}{c}-0.176 \\
(0.185)\end{array}$ & $\begin{array}{c}0.041 \\
(0.090)\end{array}$ & $\begin{array}{c}-0.186 \\
(0.182)\end{array}$ \\
\hline$A R E A$ & $\begin{array}{c}0.006 \\
(0.101)\end{array}$ & $\begin{array}{l}-0.300 \\
(0.210)\end{array}$ & $\begin{array}{c}0.010 \\
(0.101)\end{array}$ & $\begin{array}{l}-0.274 \\
(0.209)\end{array}$ \\
\hline \multicolumn{5}{|c|}{ Other controls } \\
\hline CITSSC & $\begin{array}{c}-0.055 \\
(0.056)\end{array}$ & $\begin{array}{c}0.293 \\
(\mathbf{0 . 1 1 6})\end{array}$ & $\begin{array}{c}-0.063 \\
(0.056)\end{array}$ & $\begin{array}{c}0.302 \\
(0.111)\end{array}$ \\
\hline CITSSEC & $\begin{array}{c}0.653 \\
(0.224)\end{array}$ & $\begin{array}{c}1.447 \\
(0.405)\end{array}$ & $\begin{array}{c}0.676 \\
(0.223)\end{array}$ & $\begin{array}{c}1.090 \\
(0.404)\end{array}$ \\
\hline \# observations & 3,518 & 497 & 3,494 & 490 \\
\hline log-likelihood & $-3,460.4$ & -568.5 & $-3,439.5$ & -559.9 \\
\hline
\end{tabular}

Note: Variables are in logs. Robust standard errors are in parentheses. All regressions include dummies for Non chemical companies, Missing value for R\&D and SALES, Inventor country, Applicant country, Year of application and Technological field. 
Table 5: Citations made to previous patents. Share of local, national, international and self citations in biotechnology and traditional chemical.

\begin{tabular}{lccc}
\hline & Biotechnology & $\begin{array}{c}\text { Traditional } \\
\text { chemicals }\end{array}$ & Total \\
\hline Share of local citations & 7.6 & 4.8 & 5.2 \\
Share of national citations & 7.2 & 9.3 & 9.0 \\
Share of international citations & 69.7 & 53.9 & 56.1 \\
Share of self-citations & 15.4 & 31.9 & 29.7 \\
\hline
\end{tabular}

Source: Elaboration from the EPO. Sample: 4,262 citing patents and 7,304 cited patents. 
Appendix 1: NUTS2 and NUTS3 classification used in the paper

\begin{tabular}{|c|c|c|c|c|c|}
\hline at111 & Mittelburgenland & $\begin{array}{l}\text { es61 } \\
7\end{array}$ & Málaga & it323 & Belluno \\
\hline at112 & Nordburgenland & $\begin{array}{l}\text { es61 } \\
8\end{array}$ & Sevilla & it324 & Treviso \\
\hline at113 & Südburgenland & es62 & Murcia & it325 & Venezia \\
\hline at121 & Mostviertel-Eisenwurzen & $\begin{array}{l}\text { es63 } \\
1\end{array}$ & Ceuta & it326 & Padova \\
\hline at122 & Niederösterreich-Süd & $\begin{array}{l}\text { es63 } \\
2\end{array}$ & Melilla & it327 & Rovigo \\
\hline at123 & Sankt Pölten & $\begin{array}{l}\text { es70 } \\
1\end{array}$ & Las Palmas & it331 & Pordenone \\
\hline at124 & Waldviertel & $\begin{array}{l}\text { es70 } \\
2\end{array}$ & $\begin{array}{l}\text { Santa Cruz De } \\
\text { Tenerife }\end{array}$ & it332 & Udine \\
\hline at125 & Weinviertel & fi131 & Etelä-Savo & it333 & Gorizia \\
\hline at126 & Wiener Umland/Nordteil & fi132 & Pohjois-Savo & it334 & Trieste \\
\hline at127 & Wiener Umland/Südteil & fi133 & Pohjois-Karjala & it401 & Piacenza \\
\hline at13 & Vienna & fi134 & Kainuu & it402 & Parma \\
\hline at211 & Klagenfurt-Villach & fi141 & Keski-Suomi & it403 & Reggio nell'Emilia \\
\hline at212 & Oberkärnten & fi142 & Etelä-Pohjanmaa & it404 & Modena \\
\hline at213 & Unterkärnten & fi143 & Pohjanmaa & it405 & Bologna \\
\hline at221 & Graz & fi144 & Keski-Pohjanmaa & it406 & Ferrara \\
\hline at222 & Liezen & fi151 & Pohjois-Pohjanmaa & it407 & Ravenna \\
\hline at223 & Östliche Obersteiermark & fi152 & Lappi & it408 & Forlì-Cesena \\
\hline at224 & Oststeiermark & fi161 & Uusimaa (maakunta) & it409 & Rimini \\
\hline at225 & West- und Südsteiermark & fi162 & Itä-Uusimaa & it511 & Massa-Carrara \\
\hline at226 & $\begin{array}{l}\text { Westliche } \\
\text { Obersteiermark }\end{array}$ & fi171 & Varsinais-Suomi & it512 & Lucca \\
\hline at311 & Innviertel & fi172 & Satakunta & it513 & Pistoia \\
\hline at312 & Linz-Wels & fi173 & Kanta-Häme & it514 & Firenze \\
\hline at313 & Mühlviertel & fi174 & Pirkanmaa & it515 & Prato \\
\hline at314 & Steyr-Kirchdorf & fi175 & Päijät-Häme & it516 & Livorno \\
\hline at315 & Traunviertel & fi176 & Kymenlaakso & it517 & Pisa \\
\hline at321 & Lungau & fi177 & Etelä-Karjala & it518 & Arezzo \\
\hline at322 & Pinzgau-Pongau & fi2 & Åland & it519 & Siena \\
\hline at323 & Salzburg und Umgebung & fr1 & Île de France & it51a & Grosseto \\
\hline at331 & Außerfern & fr211 & Ardennes & it521 & Perugia \\
\hline at332 & Innsbruck & fr212 & Aube & it522 & Terni \\
\hline at333 & Osttirol & fr213 & Marne & it531 & Pesaro e Urbino \\
\hline at334 & Tiroler Oberland & fr214 & Haute-Marne & it532 & Ancona \\
\hline at335 & Tiroler Unterland & fr221 & Aisne & it533 & Macerata \\
\hline at341 & Bludenz-Bregenzer Wald & fr222 & Oise & it534 & Ascoli Piceno \\
\hline at342 & Rheintal-Bodenseegebiet & fr223 & Somme & it601 & Viterbo \\
\hline be1 & Région Bruxelles & fr231 & Eure & it602 & Rieti \\
\hline be21 & Antwerpen & fr232 & Seine-Maritime & it603 & Roma \\
\hline be22 & Limburg (B) & fr241 & Cher & it604 & Latina \\
\hline be23 & Oost-Vlaanderen & fr242 & Eure-et-Loir & it605 & Frosinone \\
\hline be24 & Vlaams Brabant & fr243 & Indre & it711 & L'Aquila \\
\hline be25 & West-Vlaanderen & fr244 & Indre-et-Loire & it712 & Teramo \\
\hline be3 & Région Wallonne & fr245 & Loir-et-Cher & it713 & Pescara \\
\hline be31 & Brabant Wallon & fr246 & Loiret & it714 & Chieti \\
\hline be32 & Hainaut & fr251 & Calvados & it72 & Molise \\
\hline
\end{tabular}




\begin{tabular}{|c|c|c|c|c|c|}
\hline be33 & Liège & fr252 & Manche & it721 & Isernia \\
\hline be34 & Luxembourg (B) & fr253 & Orne & it722 & Campobasso \\
\hline be35 & Namur & fr261 & Côte-d'Or & it801 & Caserta \\
\hline ch & Switzerland & fr262 & Nièvre & it802 & Benevento \\
\hline de11 & Stuttgart & fr263 & Saône-et-Loire & it803 & Napoli \\
\hline de12 & Karlsruhe & fr264 & Yonne & it804 & Avellino \\
\hline de13 & Freiburg & fr301 & Nord & it805 & Salerno \\
\hline de14 & Tübingen & fr302 & Pas-de-Calais & it911 & Foggia \\
\hline de21 & Oberbayern & fr411 & Meurthe-et-Moselle & it912 & Bari \\
\hline de22 & Niederbayern & fr412 & Meuse & it913 & Taranto \\
\hline de23 & Oberpfalz & fr413 & Moselle & it914 & Brindisi \\
\hline de24 & Oberfranken & fr414 & Vosges & it915 & Lecce \\
\hline de25 & Mittelfranken & fr421 & Bas-Rhin & it921 & Potenza \\
\hline de26 & Unterfranken & fr422 & Haut-Rhin & it922 & Matera \\
\hline de27 & Schwaben & fr431 & Doubs & it931 & Cosenza \\
\hline de3 & Berlin & fr432 & Jura & it932 & Crotone \\
\hline de4 & Brandenburg & fr433 & Haute-Saône & it933 & Catanzaro \\
\hline de5 & Bremen & fr434 & Territoire de Belfort & it934 & Vibo Valentia \\
\hline de6 & Hamburg & fr511 & Loire-Atlantique & it935 & Reggio di Calabria \\
\hline de71 & Darmstadt & fr512 & Maine-et-Loire & ita01 & Trapani \\
\hline de72 & Gießen & fr513 & Mayenne & ita02 & Palermo \\
\hline de73 & Kassel & fr514 & Sarthe & ita03 & Messina \\
\hline de8 & Mecklenburg-Vorpom. & fr515 & Vendée & ita04 & Agrigento \\
\hline de91 & Braunschweig & fr521 & Côte-du-Nord & ita05 & Caltanissetta \\
\hline de92 & Hannover & fr522 & Finistère & ita06 & Enna \\
\hline de93 & Lüneburg & fr523 & Ille-et-Vilaine & ita07 & Catania \\
\hline de94 & Weser-Ems & fr524 & Morbihan & ita08 & Ragusa \\
\hline dea1 & Düsseldorf & fr531 & Charente & ita09 & Siracusa \\
\hline dea2 & Köln & fr532 & Charente-Maritime & itb01 & Sassari \\
\hline dea3 & Münster & fr533 & Deux-Sèvres & itb02 & Nuoro \\
\hline dea4 & Detmold & fr534 & Vienne & itb03 & Oristano \\
\hline dea5 & Arnsberg & fr611 & Dordogne & itb04 & Cagliari \\
\hline deb1 & Koblenz & fr612 & Gironde & lu & Luxembourg \\
\hline deb2 & Trier & fr613 & Landes & nl1 & Noord-Nederland \\
\hline deb3 & Rheinhessen-Pfalz & fr614 & Lot-et-Garonne & nl11 & Groningen \\
\hline dec & Saarland & fr615 & Pyrénées-Atlantiques & nl12 & Friesland \\
\hline ded1 & Chemnitz & fr621 & Ariège & nl13 & Drenthe \\
\hline ded2 & Dresden & fr622 & Aveyron & $\mathrm{nl} 21$ & Overijssel \\
\hline ded3 & Leipzig & fr623 & Haute-Garonne & $\mathrm{nl} 22$ & Gelderland \\
\hline dee1 & Dessau & fr624 & Gers & $\mathrm{nl} 23$ & Flevoland \\
\hline dee2 & Halle & fr625 & Lot & nl31 & Utrecht \\
\hline dee3 & Magdeburg & fr626 & Hautes-Pyrénées & nl32 & Noord-Holland \\
\hline def & Schleswig-Holstein & fr627 & Tarn & $\mathrm{nl} 33$ & Zuid-Holland \\
\hline deg & Thüringen & fr628 & Tarn-et-Garonne & $\mathrm{nl} 34$ & Zeeland \\
\hline dk001 & København og Frederik. & fr631 & Corrèze & $\mathrm{nl} 41$ & Noord-Brabant \\
\hline dk002 & Københavns amt & fr632 & Creuse & $\mathrm{nl} 42$ & Limburg (NL) \\
\hline dk003 & Frederiksborg amt & fr633 & Haute-Vienne & $\begin{array}{l}\text { se01 } \\
1\end{array}$ & Stockholms län \\
\hline dk004 & Roskilde amt & fr711 & Ain & $\begin{array}{l}\text { se02 } \\
1\end{array}$ & Uppsala län \\
\hline dk005 & Vestsjællands amt & fr712 & Ardèche & $\begin{array}{l}\text { se02 } \\
2\end{array}$ & Södermanlands län \\
\hline & Storstrøms amt & fr713 & Drôme & $\begin{array}{l}\text { se02 } \\
3\end{array}$ & Östergötlands län \\
\hline
\end{tabular}




\begin{tabular}{|c|c|c|c|c|c|}
\hline dk007 & Bornholms amt & fr714 & Isère & $\begin{array}{l}\text { se02 } \\
4\end{array}$ & Örebro län \\
\hline dk008 & Fyns amt & fr715 & Loire & $\begin{array}{l}\text { se02 } \\
5\end{array}$ & Västmanlands län \\
\hline dk009 & Sønderjyllands amt & fr716 & Rhône & $\begin{array}{l}\text { se04 } \\
1\end{array}$ & Blekinge län \\
\hline dk00a & Ribe amt & fr717 & Savoie & $\begin{array}{l}\text { se04 } \\
4\end{array}$ & Skåne län \\
\hline dk00b & Vejle amt & fr718 & Haute-Savoie & $\begin{array}{l}\text { se06 } \\
1\end{array}$ & Värmlands län \\
\hline dk00c & Ringkøbing amt & fr721 & Allier & $\begin{array}{l}\text { se06 } \\
2\end{array}$ & Dalarnas län \\
\hline dk00d & Århus amt & fr722 & Cantal & $\begin{array}{l}\text { se06 } \\
3\end{array}$ & Gävleborgs län \\
\hline $\begin{array}{l}\mathrm{dk} 00 \\
\mathrm{e}\end{array}$ & Viborg amt & fr723 & Haute-Loire & $\begin{array}{l}\text { se07 } \\
1\end{array}$ & Västernorrlands län \\
\hline dk00f & Nordjyllands amt & fr724 & Puy-de-Dôme & $\begin{array}{l}\text { se07 } \\
2\end{array}$ & Jämtlands län \\
\hline es111 & La Coruña & fr811 & Aude & $\begin{array}{l}\text { se08 } \\
1\end{array}$ & Västerbottens län \\
\hline es112 & Lugo & fr812 & Gard & $\begin{array}{l}\text { se08 } \\
2\end{array}$ & Norrbottens län \\
\hline es113 & Orense & fr813 & Hérault & $\begin{array}{l}\text { se09 } \\
1\end{array}$ & Jönköpings län \\
\hline es114 & Pontevedra & fr814 & Lozère & $\begin{array}{l}\text { se09 } \\
2\end{array}$ & Kronobergs län \\
\hline es211 & Álava & fr815 & Pyrénées-Orientales & $\begin{array}{l}\text { se09 } \\
3\end{array}$ & Kalmar län \\
\hline es212 & Guipúzcoa & fr821 & Alpes-de-Haute-Prov. & $\begin{array}{l}\text { se09 } \\
4\end{array}$ & Gotlands län \\
\hline es213 & Vizcaya & fr822 & Hautes-Alpes & se0a1 & Hallands län \\
\hline es22 & Comunidad de Navarra & fr823 & Alpes-Maritimes & se0a2 & Västra Götalands län \\
\hline es23 & La Rioja & fr824 & Bouches-du-Rhône & ukc1 & Tees Valley and Durham \\
\hline es241 & Huesca & fr825 & Var & ukc2 & Northumb., Tyne and Wear \\
\hline es242 & Teruel & fr826 & Vaucluse & ukd1 & Cumbria \\
\hline es243 & Zaragoza & fr831 & Corse-du-Sud & ukd2 & Cheshire \\
\hline es3 & Comunidad de Madrid & fr832 & Haute-Corse & ukd3 & Greater Manchester \\
\hline es411 & Avila & fr9 & French overseas depts. & ukd4 & Lancashire \\
\hline es412 & Burgos & ie & Ireland & ukd5 & Merseyside \\
\hline es413 & León & it111 & Torino & uke1 & East Riding, N. Lincolnshire \\
\hline es414 & Palencia & it112 & Vercelli & uke2 & North Yorkshire \\
\hline es415 & Salamanca & it113 & Biella & uke3 & South Yorkshire \\
\hline es416 & Segovia & it114 & Verbano-Cusio-Ossola & uke4 & West Yorkshire \\
\hline es417 & Soria & it115 & Novara & ukf1 & Derbyshire, Nottinghamshire \\
\hline es418 & Valladolid & it116 & Cuneo & ukf2 & Leicester, Rutland, Northants \\
\hline es419 & Zamora & it117 & Asti & ukf3 & Lincolnshire \\
\hline es421 & Albacete & it118 & Alessandria & ukg1 & Hereford, Worcester, Warks \\
\hline es422 & Ciudad Real & it13 & Liguria & ukg2 & Shropshire and Staffordshire \\
\hline es423 & Cuenca & it131 & Imperia & ukg3 & West Midlands \\
\hline es424 & Guadalajara & it132 & Savona & ukh1 & East Anglia \\
\hline es425 & Toledo & it133 & Genova & ukh2 & Bedfordshire, Hertfordshire \\
\hline es431 & Badajoz & it134 & La Spezia & ukh3 & Essex \\
\hline es432 & Cáceres & it201 & Varese & uki1 & Inner London \\
\hline es511 & Barcelona & it202 & Como & uki2 & Outer London \\
\hline es512 & Gerona & it203 & Lecco & ukj1 & Berkshire, Bucks, Oxfordshire \\
\hline
\end{tabular}




$\begin{array}{ll}\text { es513 } & \text { Lérida } \\ \text { es514 } & \text { Tarragona } \\ \text { es521 } & \text { Alicante } \\ \text { es522 } & \text { Castellón de la Plana } \\ \text { es523 } & \text { Valencia } \\ \text { es53 } & \text { Illes Balears } \\ \text { es611 } & \text { Almería } \\ \text { es612 } & \text { Cadiz } \\ \text { es613 } & \text { Córdoba } \\ \text { es614 } & \text { Granada } \\ \text { es615 } & \text { Huelva } \\ \text { es616 } & \text { Jaén }\end{array}$

it204 Sondrio

it205 Milano

it206 Bergamo

it207 Brescia

it208 Pavia

it209 Lodi

it20a Cremona

it20b Mantova

it311 Bolzano-Bozen

it312 Trento

it321 Verona

it322 Vicenza ukj2 Surrey, East and West Sussex

ukj3 Hampshire and Isle of Wight

ukj4 Kent

ukk1 Gloucester, Wilts, N.

Somerset

ukk2 Dorset and Somerset

ukk3 Cornwall and Isles of Scilly

ukk4 Devon

ukl1 West Wales and The Valleys

ukl2 East Wales

ukm1 North Eastern Scotland

ukm2 Eastern Scotland

ukm3 South Western Scotland

ukm4 Highlands and Islands

Source: Eurostat (1999) 